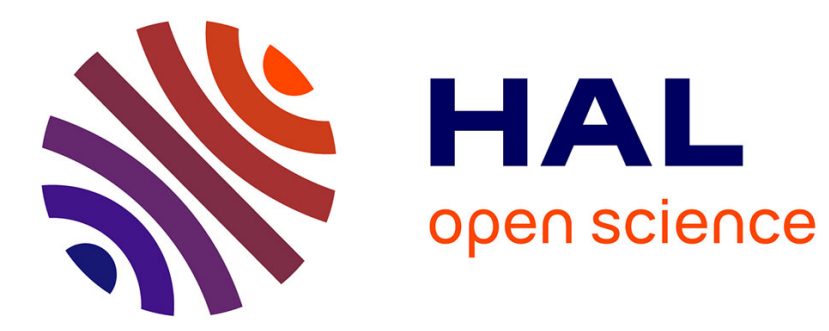

\title{
The GK Rat Beta-Cell: A Prototype for the Diseased Human Beta-Cell in Type 2 Diabetes?
}

B. Portha, G. Lacraz, M. Kergoat, F. Homo-Delarche, M.-H. Giroix, D. Bailbé, M.N. Gangnerau, M. Dolz, C. Tourrel-Cuzin, J. Movassat

\section{To cite this version:}

B. Portha, G. Lacraz, M. Kergoat, F. Homo-Delarche, M.-H. Giroix, et al.. The GK Rat BetaCell: A Prototype for the Diseased Human Beta-Cell in Type 2 Diabetes?. Molecular and Cellular Endocrinology, 2008, 297 (1-2), pp.73. 10.1016/j.mce.2008.06.013 . hal-00532043

\section{HAL Id: hal-00532043 https://hal.science/hal-00532043}

Submitted on 4 Nov 2010

HAL is a multi-disciplinary open access archive for the deposit and dissemination of scientific research documents, whether they are published or not. The documents may come from teaching and research institutions in France or abroad, or from public or private research centers.
L'archive ouverte pluridisciplinaire HAL, est destinée au dépôt et à la diffusion de documents scientifiques de niveau recherche, publiés ou non, émanant des établissements d'enseignement et de recherche français ou étrangers, des laboratoires publics ou privés. 


\section{Accepted Manuscript}

Title: The GK Rat Beta-Cell: A Prototype for the Diseased Human Beta-Cell in Type 2 Diabetes?

Authors: B. Portha, G. Lacraz, M. Kergoat, F. Homo-Delarche, M.-H. Giroix, D. Bailbé, M.N. Gangnerau, M. Dolz, C. Tourrel-Cuzin, J. Movassat

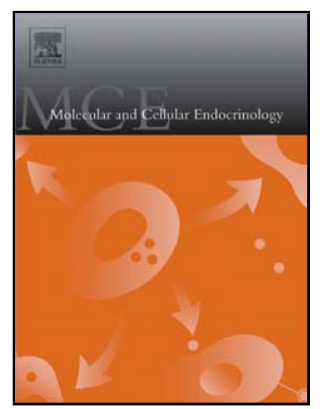

PII: S0303-7207(08)00272-4

DOI: doi:10.1016/j.mce.2008.06.013

Reference: MCE 6901

To appear in: $\quad$ Molecular and Cellular Endocrinology

Received date: $\quad$ 17-2-2008

Revised date: $\quad 3-6-2008$

Accepted date: $\quad 12-6-2008$

Please cite this article as: Portha, B., Lacraz, G., Kergoat, M., Homo-Delarche, F., Giroix, M.-H., Bailbé, D., Gangnerau, M.N., Dolz, M., Tourrel-Cuzin, C., Movassat, J., The GK Rat Beta-Cell: a Prototype for the Diseased Human Beta-Cell in Type 2 Diabetes?, Molecular and Cellular Endocrinology (2007), doi:10.1016/j.mce.2008.06.013

This is a PDF file of an unedited manuscript that has been accepted for publication. As a service to our customers we are providing this early version of the manuscript. The manuscript will undergo copyediting, typesetting, and review of the resulting proof before it is published in its final form. Please note that during the production process errors may be discovered which could affect the content, and all legal disclaimers that apply to the journal pertain. 
The GK Rat Beta-Cell : a Prototype for the Diseased Human Beta-Cell in Type 2 Diabetes?

B. Portha ${ }^{1}$, G. Lacraz ${ }^{1}$, M. Kergoat ${ }^{2}$, F. Homo-Delarche ${ }^{1}$, M-H. Giroix ${ }^{1}$, D. Bailbé ${ }^{1}$, MN. Gangnerau $^{1}$, M. Dolz ${ }^{1}$, C. Tourrel-Cuzin ${ }^{1}$, J. Movassat $^{1}$

${ }^{1}$ Groupe Biologie et Pathologie du Pancréas Endocrine, Laboratoire de Physiopathologie de la Nutrition, UMR CNRS 7059, Université Paris-Diderot / UP7, Paris, France

${ }^{2}$ MERCK-SERONO, Centre de Recherche, Chilly-Mazarin, France

Corresponding author:

Prof. Bernard Portha, Laboratoire de Physiopathologie de la Nutrition, CNRS UMR 7059, Université Paris-Diderot, 2, place Jussieu, 75251 Paris Cedex 05, France.

Phone: +33-1-44-27-50-11; Fax: +33-1-44-27-78-91; e-mail: portha@univ-paris-diderot.fr

Key Words: type 2 diabetes, GK rat, beta-cell, development, neogenesis, glucotoxicity, inflammation, oxidative stress, insulin secretion, metabolic programming, genetic, epigenetic

\begin{abstract}
:
Increasing evidence indicates that decreased functional beta-cell mass is the hallmark of type 2 diabetes mellitus (T2D). Nowadays, the debate focuses on the possible mechanisms responsible for abnormal islet microenvironment, decreased beta-cell number, impaired betacell function, and their multifactorial aetiologies. This review is aimed to illustrate to what extend the Goto-Kakizaki rat, one of the best characterized animal models of spontaneous $\mathrm{T} 2 \mathrm{D}$, has proved be a valuable tool offering sufficient commonalities to study these aspects. We propose that the defective beta-cell mass and function in the GK model reflect the complex interactions of multiple pathogenic players: (i) several independent loci containing genes responsible for some diabetic traits (but not decreased beta-cell mass); (ii) gestational metabolic impairment inducing an epigenetic programming of the pancreas (decreased betacell neogenesis and/or proliferation) which is transmitted to the next generation; and (iii) loss of beta-cell differentiation due to chronic exposure to hyperglycemia/hyperlipidemia, inflammatory mediators, oxidative stress and to perturbed islet microarchitecture.
\end{abstract}

Short running title:

The GK rat beta-cell. 
Type 2 diabetes (T2D) arises when the endocrine pancreas fails to secrete sufficient insulin to cope with the metabolic demand [Donath and Halban, 2004; Weir and Bonner-Weir, 2004; Rhodes, 2005], because of beta-cell secretory dysfunction and/or decreased beta-cell mass. Hazard of invasive sampling and lack of suitable non-invasive methods to evaluate beta-cell mass and beta-cell functions are strong limitations for studies of the living pancreas in human. In such a perspective, appropriate rodent models are essential tools for identification of the mechanisms that increase the risk of abnormal beta-cell mass/function and of T2D. Some answers to these major questions are available from studies using the endocrine pancreas of the Goto-Kakizaki (GK) rat model of T2D. It is the aim of the present paper to review the common features that makes studies of the GK beta-cell so compelling.

\section{1/ The Goto-Kakizaki Wistar (GK) rat, a valuable model of spontaneous T2D}

The GK line was established by repeated inbreeding from Wistar (W) rats selected at the upper limit of normal distribution for glucose tolerance [Goto et al, 1975; Goto et al. 1988; Portha et al, 2001; Ostenson, 2001; Portha, 2005; Portha et al. 2007].

Until the end of the 1980s, GK rats were bred only in Sendai [Goto et al, 1975]. Colonies were then initiated with breeding pairs from Japan, in Paris, France [Portha et al, 1991], Stockholm, Sweden [Ostenson, 2001], Cardiff, UK [Lewis et al, 1996], Coimbra, Portugal [Duarte et al, 2004], Tampa, USA [Villar-Palasi and Farese, 1994]. Some other colonies existed for shorter periods during the 1990s in London, UK [Hughes et al. 1994], Aarhus, Denmark, and Seattle, USA [Metz et al, 1999]. There are also GK rat colonies derived from Paris in Oxford, UK [Wallis et al, 2004] and Brussels, Belgium [Sener et al, 2001]. Also, GK rats are available commercially from the Japanese breeders Charles River Japan (Yokohama), Oriental Yeast (Tokyo), Clea (Osaka), and Takeda Lab Ltd (Osaka), and from Taconic, USA (www.taconic.com).

In our colony (GK/Par subline) maintained since 1989, the adult GK/Par body weight is 10 $30 \%$ lower than that of age and sex-matched control animals. In male GK/Par rats, non-fasting plasma glucose levels are typically $10-14 \mathrm{mM}$ (6-8 $\mathrm{mM}$ in age-matched Wistar (W) outbred controls). Despite the fact that GK rats in the various colonies bred in Japan and outside over 20 years have maintained rather stable degree of glucose intolerance, other characteristics such as beta cell number, insulin content and islet metabolism and secretion have been reported to differ between some of the different colonies, suggesting that different local breeding environment and/or newly introduced genetic changes account for contrasting phenotypic properties.

Presently it is not clear whether the reported differences are artefactual or true. Careful and extensive identification of GK phenotype within each local subline is therefore necessary when comparing data from different GK sources (Table 1). As an illustration of this point, we have recently compared insulin and glucagon release by GK rats obtained from Taconic (GK/Tac) to that of GK/Par rats, using the perfused pancreas technique (Fig 1). Despite no significant difference as far as body weight, basal postabsortive plasma glucose level and glucose tolerance to i.v. glucose in vivo are concerned ( 8 wks old males), a milder impairment of insulin release in response to glucose (preservation of first phase) or arginine, together with an increased glucagons release in response to arginine, were found in the GK/Taconic as compared to the GK/Par rats. For further details concerning the pathogenic sequence culminating in the chronic hyperglycaemia at adult age in the GK/Par rat, please refer to recent reviews [Ostenson, 2001; Portha, 2005; Portha et al. 2007]. 


\section{2/Less beta-cells}

\section{1/ T2D human pancreas}

Whether beta cell mass is decreased in T2D has been controversial for a long time [MacLean and Ogilvie, 1955; Gepts, 1957; Saito et al. 1979; Stefan et al., 1982; Rahier et al. 1983; Kloppel et al. 1985; Clark et al. 1988; Sempoux et al. 2001; Sakuraba et al. 2002]. These discrepancies are in part due to the paucity of available data in humans. It is difficult to obtain pancreatic tissue from humans, since this usually only becomes available at autopsy, when the pancreas may have undergone autolysis. Also, reliable clinical information about autopsy cases is often unavailable. It is therefore not surprising that there are few studies of islet morphology in humans with diabetes, and in most of these, only small numbers of cases were included. However, it was suggested a long time ago that beta cell mass is in fact reduced in T2D [Hellerstrom, 1984; Kloppel et al. 1985]. Indeed several recent studies utilizing post-mortem and surgical pancreas specimens have provided valuable information on the pathogenesis of islet beta-cell failure in T2D [Guiot et al. 2001; Sakuraba 2002; Butler et al. 2003; Ehao et al. 2003; Yoon et al. 2003; Deng et al. 2004; Anello et al. 2005] and all of them have shown a reduction in beta cell mass in T2D. Among these is a landmark study of beta-cell volume together with markers of beta-cell proliferation and apoptosis, taking advantage of the unique autopsy material (124 human pancreases) available at the Mayo Clinic to study from cases with and without diabetes and matched for obesity [Butler et al. 2003]. The study showed relative beta cell volume to be increased by $50 \%$ in obese compared with lean nondiabetic pancreas and was attributed to increased neogenesis of islets from exocrine ductal tissue. IGT obese and T2D obese subjects had a $40 \%$ and $63 \%$ beta-cell volume deficit respectively, compared with weight-matched controls. Lean T2D subjects had a $41 \%$ deficit of beta-cell volume compared with lean controls. Furthermore, the decreased volume was not a consequence of reduced beta-cell proliferation, but was associated with increased beta-cell death by apoptosis [Butler et al. 2003]. This last finding was confirmed in an independent study, with increased activities of caspase- 3 and caspase- 8 [Marchetti et al. 2004]. Interestingly, these last authors reported that metformin was found to exert an antiapoptotic effect on the human diabetic beta cells in vitro, which was paralleled by a reduction of caspase- 3 and caspase- 8 activities [Marchetti et al. 2004]. It is important to remark that, even if accelerated, the rate of beta-cell apoptosis in T2D rarely progresses to near-complete loss, even after decades of the disease. Although it is often assumed that accelerated apoptosis of beta-cells is important for the pathogenesis of T2D, limitations in beta-cell replication and/or neogenesis could be just as important. It is remarkable that despite the decreased total pancreatic beta-cell mass, the percentage of beta-cells within isolated islets was only slightly reduced (by 10\%) in T2D patients as compared with controls [Del Guerra et al. 2005]. Moreover, the fact that loss of beta-cell mass was evident in subjects with IGT [Butler et al. 2003] suggests that beta-cell mass changes are not necessarily confined to late-stage T2D. Some glucagon or insulin positive cells were observed in the pancreatic ducts in T2D pancreases [Yoon et al. 2003]. Beta cell neogenesis might be increased in T2D because larger numbers of duct cells were found to be insulin immunoreactive in T2D than in normal controls [Jones and Clark, 2001].These findings support alpha and beta cell neogenesis from precursor duct cells in adult T2D patients, in the face of a low beta cell replication rate [Yoon et al. 2003].

Most of these studies in human pancreatic tissues suffer from methodological limitations: $1 /$ the relative beta cell volume is generally used as a surrogate of beta cell mass. As total pancreas weight is not available, this approach will be in error to the extent that there were differences in the overall mean pancreatic weight among groups; $2 /$ it is difficult to distinguish between the two mechanisms, cell formation and cell death, in human tissue 
sections mainly because dead cells are removed rapidly from the islet by macrophages and neighboring cells, making it hard to quantify cell death; 3/ although cell proliferation can be quantified in tissue sections using markers, this only provides a single snapshot in time; 4/ these studies cannot supply prospective informations, given that they were done at autopsy. The beta-cell mass in the patients before onset of the disease is unknown. Thus individuals susceptible to diabetes possibly have limited beta-cell mass early in life, may be even in utero, due to genetic or environmental factors. If such were the case, the decrease in beta-cell mass as seen once T2D is there, would not necessarily be the consequence of the disease itself.

\section{2/ GK rat pancreas}

In the adult hyperglycaemic GK/Par rats (males or females), total pancreatic beta-cell mass is decreased (by 60\%) [Portha et al. 2001; Movassat et al. 1997]. This alteration of the beta-cell population cannot be ascribed to increased beta-cell apoptosis but is related, at least partly, to significantly decreased beta-cell replication as measured in vivo [Portha et al. 2001]. The islets isolated by standard collagenase procedure from adult GK/Par pancreases, show limited decreased beta-cell number (by $15 \%$ only) and low insulin content compared with control islets [15]. The islet DNA content was decreased to a similar extent, consistent with our morphometric data, which indicate that there is no major change in the relative contribution of beta-cells to total endocrine cells in the GK islets. In addition, the insulin content, when expressed relative to DNA, remains lower in GK islets than in control (inbred W/Par) islets, which supports a very limited degranulation in the beta-cells of diabetic animals [Giroix et al. 1999]. The distribution of various GK islet cell types appears to differs between some of the GK rat colonies. Thus, in the Stockholm colony (GK/Sto) beta-cell density and relative volume of insular cells were alike in adult GK rat and control W rats [Östenson, 2001; Abdel-Halim et al. 1993; Guenifi et al. 1995]. Similar results were reported in a GK colony in Dallas (GK/Dal) [Ohneda et al. 1993].

A meaningful set of data from our group [Movassat et al. 1999; Miralles et Portha, 2001; Plachot et al. 2001; Calderari et al. 2007] suggests that the permanently reduced betacell mass in the GK/Par model indeed reflects a limitation of beta-cell neogenesis during early fetal life and thereafter. Follow-up of the animals after delivery revealed that GK/Par pups become overtly hyperglycaemic for the first time after three to four weeks of age only (i.e. during the weaning period). Despite normoglycaemia, total beta-cell mass was clearly decreased (by 60\%) in the GK pups when compared with age-related W pups [Movassat et al. 1997]. Since this early beta-cell growth retardation in the prediabetic GK/Par rat pups cannot be ascribed to decreased beta-cell replication, nor to increased apoptosis [Movassat et al. 1997], we postulated that the recruitment of new beta-cells from the precursor pool (beta-cell neogenesis) was defective in the young prediabetic GK/Par rat. A comparative study of the development of GK/Par and $\mathrm{W}$ pancreases indicates that the beta-cell deficit (reduced by more than 50\%) starts as early as fetal age 16 days (E16) [Miralles et Portha, 2001]. During the time-window E16-E20, we detected an unexpected anomaly of proliferation and apoptosis of undifferentiated ductal cells in the GK pancreatic rudiments [Miralles et Portha, 2001; Calderari et al. 2007]. Therefore, the decreased cell proliferation and survival in the ductal compartment of the pancreas where the putative endocrine precursor cells localize, suggests that the impaired development of the beta-cell in the GK fetus could result from the failure of the proliferative and survival capacities of the endocrine precursor cells. Importantly, data from our group indicate that defective signalling through the Igf2/Igf1-R pathway represents a primary anomaly since Igf2 and Igf1-R protein expressions are already decreased within the GK pancreatic rudiment at E13.5, at a time when beta-cell mass (first wave of beta cell 
expansion) is in fact normal [Calderari et al. 2007]. Low levels of pancreatic of Igf2 associated with beta-cell mass deficiency is maintained thereafter within the fetal pancreas [Serradas et al. 2002]. We have also published data illustrating a poor proliferation and/or survival of the endocrine precursors also during neonatal and adult life [Movassat et al. 1999; Plachot et al. 2001]. All together these arguments support the notion that an impaired capacity of beta-cell neogenesis (either primary in the fetus, or compensatory in the newborn and the adult) results from the permanently decreased pool of endocrine precursors in the GK/Par pancreas [Movassat et al. 2007].

During the last few years, some important informations concerning the determinants (morbid genes vs environment impact) for basal hyperglycemia and glucose intolerance in the GK model, have been supplied. Hyperglycemia experienced during the foetal and/or early postnatal life may contribute to programming of the endocrine pancreas [Simmons, 2006]. Such a scenario also potentially applies to the GK/Par model, as GK/Par mothers are slightly hyperglycemic through their gestation and during the suckling period [Serradas et al. 1998]. Concerning the potential maternal influence on the development of T2D in the GK model, Gauguier et al. [1994] reported that adult offspring of GK/Par females crossed with W males have a more marked hyperglycemia than adult offspring of $\mathrm{W}$ females crossed with GK males, suggesting higher maternal inheritance. However, this conclusion was not confirmed in other studies [Abdel-Halim et al. 1994; Gill-Randall et al. 2004] and cross-breeding experiments do not overcome the difficulty to isolate the respective contribution of genetic vs. intrauterine environmental factors. Recently, Gill-Randall et al. [2004] have used a rat embryo transfer technique to examine more convincingly that major point. First, these authors showed that offspring from GK embryos transferred in the uterus of euglycemic W mother still develop basal hyperglycemia and postprandial glucose intolerance when adults, therefore highlighting a predominant role for genetic factors [Gill-Randall et al. 2004]. Second, they also showed that exposure of the $\mathrm{W}$ embryo hyperglycaemia in utero (as seen in the GK pregnant mother) increases the risk of hyperglycemia in adult W life [Gill-Randall et al. 2004], this clearly illustrating the notion that there exists indeed a diabetogenic role for the GK intrauterine environment. The Randall's study however did not address to insulin secretion and beta-cell mass. We have preliminary unpublished data using the same experimental embryo-transfer strategy, suggesting that GK embryos transferred in the uterus of euglycemic W mother still develop deficiency of pancreatic insulin stores and beta cell mass when adults, to the same extend as the GK rats from our stock colony. While this preliminary conclusion rather favours a major role for inheritance of morbid genes, additional studies are needed to really eliminate the option that the gestational diabetic pattern of the GK/Par mothers does not contribute to establish and/or maintain the transmission of endocrine pancreas programming from one GK/Par generation to the next one.

Studies on the offspring in crosses between GK/Par and W rats demonstrated that F1 hybrid fetuses, regardless of whether the mother was a GK or a $\mathrm{W}$ rat, exhibit decreased beta-mass and glucose-induced insulin secretion closely ressembling those in GK/GK fetuses [Serradas et al. 1998]. This finding indicates that conjunction of GK genes from both parents is not required for defective beta-cell mass to be fully expressed. We have also shown that to have one GK parent is a risk factor for a low beta-cell mass phenotype in young adults, even when the other parent is a normal $\mathrm{W}$ rat [Calderari et al. 2006].

Two functional point mutations in the promoter region of the adenyl cyclase type 3 (AC3) gene have been reported in both islets and peripheral blood of GK/Sto rats and are associated to beta-cell AC3 over expression and increased cAMP generation [Abdel-halim et al. 1998]. The contribution if any, of such a mutation to the GK beta-cell growth defect is so far unknown. 
Gauguier et al. [1996] using a quantitative trait locus (QTL) approach, have identified six independently segregating loci containing genes regulating fasting plasma glucose and insulin levels, glucose tolerance, insulin secretion and adiposity in GK/Par rats. The same conclusion was drawn by Galli et al. [1996] using GK/Sto. This established the polygenic inheritance of diabetes-related parameters in the GK rats whatever their origin. Both studies found the strongest evidence of linkage between glucose tolerance and markers spanning a region on rat chromosome 1, called Niddm1 locus. The Niddm1i locus, located at the telomeric end of chromosome 1 in the GK rat, is also a T2D susceptibility locus in humans and corresponds to human chromosome 10q24-q26 [Duggirala et aL; 1999; Grant et al. 2006]. While it must be recognized that many of the glucose-controlling locus variants reported in the GK/Par and GK/Sto rats [Gauguier et aL; 1996; Galli et al. 1996; Wallis et al. 2004] were associated in fact with hyperinsulinaemia or enhanced insulin secretion (and paradoxically not with the reverse), more recent works using congenic technology have identified on the Niddmli locus a $3.5 \mathrm{cM}$ region containing approximately ten genes, as a major susceptibility locus for defective insulin secretion [Lin et al. 2001]. It has been recently reported that beta-cell mass is intact in Niddm1 i subcongenics [Granhall et al. 2006]. Finally, no QTL association with betacell mass or beta-cell size could be found in the GK/Par rat [Ktorza and Gauguier, personnal communication of unpublished data]. Therefore, the likelihood that a genotype alteration contributes to the low beta-cell mass phenotype in the GK/Par rat, is reduced. The raised question to be answered now is whether or not epigenetic perturbation of gene expression occurs in the the developing GK pancreas and contributes to the alteration of early beta-cell growth. igf2 and igf1r genes are good candidates for such a perspective.

\section{3/ A perturbed beta cell microenvironment within and around the islets 3.1/ T2D human islets}

Many changes in the islet architecture of T2D subjects [Wittingen et al. 1974; Orci et al. 1975; Saito et al. 1979; Baetens et al. 1979; Yoon et al. 2003] have been described including fibrosis, deposition of hyalin-like material replacing beta cells, abnormal beta cell distribution within islets, reduced size and number of islets [Yoon et al. 2003; Butler et al. 2003], arteriosclerosis, and fat infiltrations [Butler et al. 2003; Zhao et al. 2003]. A prominent finding in the diabetic patients were increased alpha cell proportions within the islets in some [Yoon et al. 2003; Deng et al.2004] but not all [Del Guerra et al. 2005] studies, and remarkable heterogeneity of morphological changes of islets within the same lobe of the pancreas [Yoon et al. 2003]. This is not correlated to significant alteration of glucagon release since measurement of glucagon secretion by perifused T2D islets did not reveal marked differences versus control preparations [Deng et al. 2004].

One of the features also present in islets of most humans with T2D is amyloid deposits [Clark et al. 1988; O’Brien et al. 1994; Saito et al. 1978; Westermark et al. 1978; Sempoux et al. 2001; Butler et al. 2003]. The role of islet amyloid in the islet pathogenesis in T2D remains controversial. One argument that has been made against the pathogenic importance of both islet amyloid in T2D and cerebral amyloid in Alzheimer's disease is that not all affected cases have amyloid present [Butler et al. 2003]. It is possible that the formation of islet amyloid is secondary to hyperglycemia and not of primary importance in the pathophysiology of T2D.

Since low-grade chronic inflammation has received increasing attention in recent years as an important pathophysiological mechanism in adipocyte insulin-resistance and atherosclerosis, inflammatory phenomena may also target the islet in T2D. Very recent data indeed support such a view since increased numbers of immune cells, specifically macrophages, were found associated with pancreatic islets in T2D [Ehses et al. 2007a]. Increased islet-derived inflammatory factors such as interleukins (IL6, IL8), granulocyte 
colony-stimulating factor (GCSF) and macrophage inflammatory protein (MIP1alpha) are produced and released when human islet are exposed to a T2D milieu [Ehses et al. 2007a]. Further, this inflammatory response was found to be biologically functional as conditioned medium from human islets exposed to a T2D milieu could induce increased migration of monocytes and neutrophils. This migration was blocked by IL8 neutralization and IL8 was localized to human alpha-cells [Ehses et al. 2007a]. Thus, islet-derived inflammatory factors are regulated by the T2D milieu and may contribute to the macrophage infiltration of the human islets. Whether the presence of macrophages is causative to T2D islet pathology requires further investigation. Possibly, early infiltration of macrophages may be beneficial to islet function and plasticity. However, as the disease progresses, macrophages may play a role in accelerating pancreatic islet cell dysfunction and death. Macrophages also may be present after beta cell death, acting to phagocytose dead islet tissue.

\section{2/ GK rat islets}

The adult GK/Par pancreas exhibits two different populations of islets in situ: large islets with pronounced fibrosis [Portha et al. 2001] and heterogeneity in the staining of their beta-cells, and small islets with heavily stained beta-cells and normal architecture. One striking morphologic feature of GK rat islets is the occurrence of these big islets characterized by connective tissue separating strands of endocrine cells [Goto et al. 1988; Suzuki et al. 1992; Guenifi et al. 1995]. Accordingly, the mantle of glucagon and somatostatin cells is disrupted and these cells are found intermingled between beta-cells. These changes increase in prevalence with ageing [Suzuki et al. 1992].

Chronic inflammation at the level of the GK/Par islet has recently received demonstration and it is now considered as a a pathophysiological contributor in GK diabetes [Ehses et al. 2007a; Ehses et al. 2007b]. Using an Affymetrix microarray approach to evaluate islet gene expression in freshly isolated adult GK/Par islets, we found that $34 \%$ of the 71 genes found to be overexpressed, belong to inflammatory/immune response gene family, and $24 \%$ belong to extracellular matrix (ECM)/cell adhesion gene family [Homo-Delarche et al. 2006]. Numerous macrophages $\left(\mathrm{CD}^{+} 8^{+}\right.$and $\mathrm{MHC}$ class $\left.\mathrm{II}^{+}\right)$and granulocytes were found in/around adult GK/Par islets [Homo-Delarche et al. 2006. Up-regulation of the MHC class II gene was also reported in a recent study of global expression profiling in GK islets from commercial source (Taconic) [Ghanaat-Pour et al. 2007]. Immunolocalization with antifibronectin and anti-vWF antibodies indicated that ECM deposition progresses from intra- and peri-islet vessels, as it happens in microangiopathy [Homo-Delarche et al. 2006]. These data demonstrate that a marked inflammatory reaction accompanies GK/Par islet fibrosis and suggest that islet alterations develop in a way reminiscent of microangiopathy [Ehses et al. 2007b]. The previous reports by our group and others that increased blood flow and altered vascularisation are present in the GK/Par and GK/Sto models [Atef et al. 1994; Svensson et al. 1994; Svensson et al. 2000] are consistent with such a view. The increased islet blood flow in GK rats may be accounted for by an altered vagal nerve regulation mediated by nitric oxide, since vagotomy as well as inhibition of NO synthase normalized GK/Sto islet flow [Svensson et al. 1994]. In addition, islet capillary pressure was increased in GK/Sto rats [Carlsson et al. 1997], this defect was restored after two weeks of normalization of glycemia by phlorizin treatment. However the precise relationship between islet microcirculation and beta cell secretory function remains to be established. 


\section{4/ Multiple beta-cell functional defects. 4.1/ T2D human islets}

The insulin release defects of T2D patients have been extensively studied in vivo and are mainly characterized by impairment of glucose-stimulated insulin release. Commonly found alterations of insulin secretion in T2D patients include reduced or absent first-phase response to intravenous glucose [Kahn, 2001], delayed or blunted release after ingestion of mixed meals [Polonski, 1998], alterations in rapid pulses and ultradian oscillations [Schmitz 2002]. In addition, second-phase insulin secretion and response to nonglucose stimuli may also be reduced in vivo [Weyer, 1999; Weir et Bonner-Weir, 2004]. More direct assessment of the properties of the diabetic beta cell using isolated islets is needed to better look for alterations associated with and/or responsible for impaired insulin secretion in T2D. So far, informations related to the functional characteristics of islets from T2D patients are scarce but relatively convergent. Several groups [Fernandez-Alvarez et al. 1994; Marchetti et al. 2000; Lin et al. 2002; Deng et al. 2004; Marchetti et al. 2004; Del Guerra et al. 2005] have recently reported multiple abnormalities of insulin secretion in islets isolated from T2D donors.

The secretion defect in T2D is probably more severe than could be accounted for solely by the reduction in beta cell mass [Ahren, 2005]. The demonstration that human beta cells maintain active insulin gene transcription and translation even in amyloid-containing islets and that insulin cleavage is normal in most beta cells [Sempoux et al. 2001], suggests that the major beta cell functional problem in T2D is abnormal coupling of insulin secretion. Because islet insulin content was only slightly decreased, by $<30 \%$, in the islets of T2D patients [Ostenson et al. 2006], it is not likely that the mechanism behind the impaired insulin secretion involves deficient insulin stores but rather reduced activity of the release mechanism.

Beta cells in T2D showed modest signs of ER stress when studied in pancreatic samples or isolated islets maintained at physiological glucose concentration. However, exposure to increased glucose levels induced ER stress markers in T2D islet cells, which therefore may be more susceptible to ER stress induced by metabolic perturbations [Marchetti et al. 2007]. Accordingly, it has been proposed that factors others than ER stress may play a prominent role in beta cell dysfunction and death, or that beta cells in T2D face a condition of ER stress that is relatively compensated for periods of time, but exacerbates in case of metabolic decompensation, thus contributing to beta cell damage [Marchetti et al. 2007].

In islets isolated from the pancreas of multiorgan donors who were affected by T2D, it has been observed a clearly reduced insulin release in response to glucose in vitro, whereas the secretion in response to leucine, glutamine or the non-fuel secretagogue arginine, was only slightly affected [Deng et al. 2004; Marchetti et al. 2004; DelGuerra et al. 2005]. The pulsatile nature of glucose-induced insulin release was preserved in T2D islets, but the amplitude of the pulses was reduced [Lin et al. 2002]. Glucose stimulation normally results in the transfer of reducing equivalents to the respiratory chain, leading to hyperpolarization of the mitochondrial membrane and generation of ATP. The expression of the SLC2A2/GLUT2 gene was repeatedly reported reduced in islets from T2D patients [Gunton et al. 2005; Ostenson et al. 2006; Del Guerra et al. 2005], while the islet glucokinase expression was reported normal [Ostenson et al. 2006] or reduced [Gunton et al. 2005; Del Guerra et al. 2005]. In addition, the activity of FAD-glycerophosphate dehydrogenase, glutamateoxalacetate transaminase, or glutamate-pyruvate transaminase was lower in T2D islets than in control cells [Fernandez-Alvarez et al. 1994]. In T2D islets, glucose-induced activation of glucose oxidation and mitochondrial membrane hyperpolarization was reduced [Del Guerra et al. 2005; Anello et al. 2005]; ATP levels were lower at high glucose and the ATP/ADP ratio was blunted, in response to glucose stimulation [Anello et al. 2005]. Further support to the 
concept that mitochondria in the diabetic beta cell are in an altered state comes from electron microscopy examinations: the density volume of these organelles was significantly higher in T2D beta cells than in control cells, due to mitochondrial swelling and enlargement [Anello et al. 2005]. In the T2D islets, the increased protein expression of complex I and complex V of the respiratory chain [Anello et al. 2005] does not support the possibility for a reduced electron flux through the respiratory chain. Rather the increased expression of UCP-2 [Anello et al. 2005] could be responsible for the reduced hyperpolarization of the mitochondrial membrane, lower ATP levels, ATP/ADP ratio, and eventually, of the reduced insulin release in response to glucose. UCP-2 protein expression could be activated by an increased formation of reactive oxygen species [Krauss et al. 2003].

An association between impaired insulin response to glucose in T2D islets and greatly reduced expression of islet SNARE complex and SNARE-modulating proteins has been recently reported [Ostenson et al. 2006]. The secretory vesicle SNAREs, synaptotagmin and VAMP-2, the target membrane-SNAREs, syntaxin-1A and SNAP-25, and the cytosolic SNARE-modulating proteins nSec1 and Munc 13-1, were decreased on either or both mRNA and protein levels. Also actin levels were increased in T2D islets relative to the nondiabetic controls [Ostenson et al. 2006].

Nitrotyrosine derives from the reaction of superoxide and nitric oxide and is considered a reliable marker of oxidative stress. Also 8-hydroxy-2-deoxyguanosine concentration was significantly higher in T2D than control islets, and it was correlated with the degree of glucose-stimulated insulin release impairment [Del Guerra et al. 2005]. The concept that the functional defects found in T2D islets are related at least in part to increased oxidative stress, is also consistent with the reports of enhanced oxidative stress-related DNA damage [Sakuraba et al. 2002], increased expression of protein kinase C-beta2 and nicotinamide adenine dinucleotide phosphate reduced-oxidase [Marchetti et al. 2004] and reduced expression of manganese-superoxide and $\mathrm{Cu} / \mathrm{Zn}$ superoxide dismutases [Sakuraba et al. 2002; Marchetti et al. 2004] in T2D pancreases. On the contrary, the increased expression of catalase and glutathione peroxidase in T2D islets [Marchetti et al. 2004] suggests an attempt to enhance the elimination of ROS through pathways different from dismutase activity. Accordingly, in vitro 24-h exposure to glutathione [Del Guerra et al. 2005] or metformin [Marchetti et al. 2004], significantly improved glucose-stimulated insulin release and decreased nitrotyrosine concentration in T2D islets. These data provide direct evidence that reducing islet cell oxidative stress is a potential target for therapeutic approaches of the diabetic human beta cell. They also suggest that the functional decline of T2D islets may not be relentless and can be, at least in part, reversible. This last conclusion is also supported by the observation that the impaired insulin release in islets of T2D patients can be reversed in vitro by GLP-1 [Ostenson et al. 2006]. Such a normalisation of the insulin response after GLP-1 in T2D patients was demonstrated in previous in vivo studies [Gutniak et al. 1992].

Recently, islets of T2D patients demonstrated marked downregulation of the aryl hydrocarbon receptor nuclear translocator (ARNT, also called hypoxia-induced factor 1 beta or HIF1 $\beta$ ) which regulates a number of genes involved in vascular function and hypoxic response including VEGF, PAI1 and EPO [Gunton et al. 2005].

Figure 2 illustrates a compendium of the abnormal intracellular sites so far identified in human T2D islets.

The causes underlying the defective insulin secretion in T2D are complex and multiple. It is also liable that one single defect is not sufficient for eliciting a defective function of that degree as diabetes develops, because compensation in other mechanisms may 
take place. The determinants for beta cell dysfunction in T2D include genetic, environmental and intrauterine/perinatal factors [Gerich, 1998].

While several rare monogenic forms diabetes (maturity-onset diabetes of the young, MODY), have been described, the genetic basis of T2D is clearly much more complex. T2D is believed to be a polygenic disease in which variations within multiple genes, each adding some risk [Laakso, 2007; Frayling and Mc Carthy, 2007; Lee and Attie, 2007]. Through various genetic approaches, polymorphisms within numerous genes relating to pancreatic islet function have been discovered that are associated with decreased/increased risk of T2D. Of particular note are polymorphisms of PPARg, PPARg coactivator 1-a (PGC1a), transcription factor Kruppellike factor 11 (KLF11), transcription factor 7-like 2 (TCF7L2), calpain 10 (CAP10), KCNJ11 (Kir6.2), and allele III of a variable number tandem repeat $0.5 \mathrm{~kb}$ upstream of the insulin genes (INS-VNTR) [Laakso, 2007; Lee and Attie, 2007]. For the majority of these polymorphisms, it is uncommon for a significantly increased T2D risk to be shown in more than one or a few population cohorts, consistent with enormous heterogeneity in heritability for this condition. Apparent exceptions are the variants in the transcription factor TCF7L2 and of KCNJ11 (Kir6.2) [Laakso, 2007; Frayling and Mc Carthy, 2007; Lee and Attie, 2007. Interestingly, the increased risk of T2D conferred by variants in TCF7L2 involves the enteroinsular axis, enhanced expression of the gene in islets, and impaired insulin secretion [Lyssenko et al. 2007].

There is also evidence, that maternal hyperglycemia in diabetic pregnancy is also an early life environmental risk factor for T2D [Dabelea and Pettitt, 2001]. In other words, the intrauterine metabolic environment may exert remote effects on the adult beta-cell health (metabolic imprinting of the beta-cell) [Simmons, 2006].

\section{2/ GK rat islets}

As for pancreatic beta-cell mass, there is some controversy regarding the content of pancreatic hormones in GK rats. In the adult hyperglycemic GK/Par rats (males), total pancreatic insulin stores are decreased by 60-40\%) [Portha et al. 2001]. In other GK rat colonies (Stockholm, Japan, Seattle, Tampa), insulin store values have been found similar or more moderately decreased, compared with control rats [Östenson et al. 1993b; Abdel-Halim et al. 1993; Suzuki et al. 1997; Salehi et al. 1999; Metz et al. 1999]. No major alteration in pancreatic glucagon content, expressed per pancreatic weight, has been demonstrated in GK/Sto rats [Abdel-Halim et al. 1993], although the total alpha-cell mass was decreased by about 35\% in adult GK/Par rats [Movassat et al. 1997]. The peripheral localization of glucagon-positive cells in $\mathrm{W}$ islets was replaced in GK/Sto rats with a more random distribution throughout the core of the islets [Guest et al. 2002]. Pancreatic somatostatin content was slightly but significantly increased in GK/Sto rats [Abdel Halim et al. 1993].

Glucose-stimulated insulin biosynthesis in freshly isolated GK/Par, GK/Jap or GK/Sto islets has been reported grossly normal [Giroix, Vesco, et al. 1993; Nagamatsu 1999; Guest et al. 2002]. The rates of biosynthesis, processing and secretion of newly synthesized (pro)insulin were comparable [Guest et al. 2002]. This is remarkable in the face of markedly lower prohormone convertase PC2 immunoreactivity and expression in the GK/Sto islets, while the expression patterns of insulin, PC1, PC2, carboxypeptidase E (CPE) remained normal [Guest et al. 2002]. Circulating insulin immunoreactivity in GK/Sto rats was predominantly insulin 1 and 2 in the expected normal ratios with no (pro)insulin evident. The finding that proinsulin biosynthesis and processing of proinsulin appeared normal in adult GK rats suggests that the depletion of secreted constituents in beta-cells does not arise from a failure to recognize glucose as an activator of prohormone biosynthesis and granule biogenesis. Rather it points to an inability of the beta-cell population as a whole to meet the 
demands upon insulin secretion imposed by chronic hyperglycemia in vivo. Although circulating insulin levels did not differ between GK and W rats, they were inappropriate for the level of glycemia, indicative of a secretory defect.

Impaired glucose-stimulated insulin secretion has been repeatedly demonstrated in GK rats (whatever the colony), in vivo [Portha et al. 1991; Gauguier et al. 1994, 1996; Galli et al. 1996; Salehi et al. 1999], in the perfused isolated pancreas [Portha et al. 1991; Östenson et al. 1993; Abdel-Halim et al. 1993, 1994, 1996), and in freshly islolated islets (Östenson et al. 1993; Giroix et al. 1993a; Giroix et al. 1993b; Hughes et al. 1994]. A number of alterations or defects have been shown in the stimulus-secretion coupling for glucose in GK islets. GLUT2 is underexpressed, but not likely to the extent that it could explain the impairment of insulin release [Ohneda et al. 1993]. This assumption is supported by the fact that glucokinase/hexokinase activities are normal in GK rat islets [Östenson et al. 1993a; Tsuura et al. 1993; Giroix et al. 1993c]. In addition, glycolysis rates in GK rat islets are unchanged or increased compared with control islets [Östenson et al. 1993b; Giroix et al. 1993a; Giroix, et al. 1993b; Giroix et al. 1993c; Hughes et al. 1994, 1998; Ling et al. 1998, 2001]. Furthermore, oxidation of glucose has been reported decreased [Giroix et al. 1993b], unchanged [Östenson et al. 1993b; Hughes et al. 1994, 1998; Giroix et al. 1993c], or even enhanced [Ling et al. 1998]. Also, lactate dehydrogenase gene expression [this paper, Fig3] and lactate production [Ling et al. 1998] are increased and pyruvate dehydrogenase activity is decreased [Zhou et al. 1995] in GK rat islets. In GK/Par islets, we showed that mitochondria of exhibit a specific decrease in the activities of FAD-dependent glycerophosphate dehydrogenase [Giroix et al. 1993b; Giroix et al. 1993c] and branched-chain ketoacid dehydrogenase [Giroix et al. 1999]. Although this certainly could contribute to lower oxidation rates, it does not exclude other mechanisms. Indeed, we found that the beta-cells of adult GK/Par rats had a significantly smaller mitochondrial volume compared to control beta-cells [Serradas et al. 1995]. No major deletion or restriction fragment polymorphism could be detected in mtDNA from adult GK/Par islets [Serradas et al. 1995]; however, they contained markedly less mtDNA than in control islets. The lower islet mtDNA was paralleled by decreased content of some islet $\mathrm{mt}$ mRNAs such as cytochrome b [Serradas et al. 1995]. In accordance with this, insufficient increase of ATP generation in response to high glucose was shown by our group [Giroix et al. 1993c]. This supports the hypothesis that the defective insulin response to glucose in GK islet is accounted for by an impaired ATP production, closure of the ATP-regulated $\mathrm{K}+$-channels [Tsuura et al. 1993] and impaired elevation of intracellular [ $\left.\mathrm{Ca}^{2+}\right]$ [Hughes et al. 1998; Marie et al. 2001; Dolz et al. 2005]. Such a view validated in the GK/Par beta-cell, is however contradictory to the reports in GK/Sto and GK/Sea islets that the rate of ATP production is unimpaired [Ling et al. 1998; Metz et al. 1999]. Other energy metabolism defects identified in GK/Sto islets, include increased glucose cycling due to increased glucose-6- phosphatase activity (Östenson et al. 1993b; Ling et al. 1998); impaired glycerol phosphate shuttle due to markedly reduced activity of the FAD-linked glycerol phosphate dehydrogenase [Östenson et al. 1993a; MacDonald et al. 1996], and decreased pyruvate carboxylase activity [MacDonald et al. 1996]. It is possible that these alterations may affect ATP concentrations locally. However, the enzyme dysfunctions were restored by normalization of glycemia in GK/Sto rats [MacDonald et al. 1996; Ling et al. unpublished observations], but with only partial improvement of glucose-induced insulin release. Hence, it is likely that these altered enzyme activities result from a glucotoxic effect rather than being primary causes behind the impaired secretion. Also, lipotoxic effects leading to defective insulin release have been observed in GK rats on high-fat diet [Shang et al. 2002; Briaud et al. 2002], possibly mediated by a mechanism partly involving modulation of UCP- 2 expression. 
Phosphoinositides [Dolz et al. 2005] and cyclicAMP metabolism [Dolz et al. 2005, 2006] are also affected in GK/Par islets. While carbachol was able to promote normal inositol generation in GK/Par islets, high glucose failed to increase inositol-phosphate accumulation [Dolz et al. 2005]. The inability of glucose to stimulate IPs production is not related to defective phospholipase $\mathrm{C}$ activity per se (total activity in islet homogenates is normal). It is rather linked to abnormal targeting of the phosphorylation of phosphoinositides: the activity of phosphatidyl-inositol kinase, which is the first of the two phosphorylating activities responsible for the generation of phosphatidyl-inositol biphosphate, is clearly reduced [Dolz et al. 2005]. Moreover, deficient calcium handling and ATP supply in response to glucose probably also contribute to abnormal activation of PI kinases and phospholipase C.

Concerning cAMP, it is remarkable that its intracellular content is very high in GK/Par beta-cells already at low glucose [Dolz et al. 2005]. This is related to increased expression of the adenylyl cyclase isoforms 1, 2 and 3, and of the GaS and Gaolf proteins while the phosphodiesterases PDE3B and PDE1C isoforms are decreased [Dolz et al. 2005, 2006]. Furthermore, cAMP is not further enhanced at increasing glucose concentrations (at variance with the situation in normal beta-cells) [Dolz et al. 2005, 2006]. This suggests that there exists a block in the steps linking glucose metabolism to activation of adenylate cyclase in the GK/Par beta-cell. An attractive possibility which has been explored in the GK/Sto rat, is that increased AC3 is due to functional mutations in the promoter region of the Ac3 gene [Abdel-Halim et al. 1998]. We do not retain this hypothesis in the GK/Par islet since we found that the expression of the $\mathrm{AC} \mathrm{1,2}$ and 3, and of the $\mathrm{G} \alpha \mathrm{S}$ and Goolf proteins, are not increased in the prediabetic GK/Par islets (Fig 3). The constitutively increased cAMP production may enhance the activity of lactate dehydrogenase [Derda et al. 1980]. This would in turn lead to increased glucose utilization and reduced cytoplasmic pool of NADH. It is well documented that altered NADH/NAD ratio is associated with impaired glucose-induced insulin release [Eto et al. 1999]. The increased cAMP production has also offered the possibility to fully restore the beta-cell secretory competence to glucose in GK/Par as well as GK/Sto islets [Abdel-Halim et al. 1996; Dolz et al. 2006] with a clear biphasic response [Dolz et al. 2006]. This also proves that the glucose-incompetence of the GK/Par beta-cell is not irreversible, and emphasizes the usefulness of GLP-1 as a therapeutic agent in T2D. Also, cholinergic stimulation has been demonstrated to restore glucose-induced insulin secretion from GK/Sto as well as GK/Par islets [Guenifi et al. 2001; Dolz et al. 2005]. We have proposed that such a stimulation is not mediated through activation of the PKC pathway, but via a paradoxical activation of the cAMP/PKA pathway to enhance $\mathrm{Ca}^{2+}$-stimulated insulin release in the GK/Par beta-cell [Dolz et al. 2005].

Along to these upstream abnormalities, important defects reside late in signal transduction i.e., in the exocytotic machinery. Indeed, glucose-stimulated insulin secretion was markedly impaired in GK/Sto, GK/Jap, GK/Sea and GK/Par islets also when the islets were depolarized by a high concentration of potassium chloride and the ATP-regulated K+channels kept open by diazoxide [Okamoto et al. 1995; Abdel-Halim et al. 1996; Metz et al. 1999]. Similar results were obtained when insulin release was induced by exogenous calcium in electrically permeabilized GK/Jap islets [Okamoto et al. 1995]. In fact, markedly reduced expression of several exocytotic SNARE complex proteins, important for the docking and fusion between insulin granules and beta-cell membrane, have been demonstrated in GK/Sto and GK/Jap islets [Nagamatsu et al. 1999; Gaisano et al. 2002; Zhang et al. 2002]. Thus, a reduced number of docking granules accounts for impaired beta-cell secretion [OharaImaizumi et al. 2004] and this defect may partly be related to glucotoxicity [Gaisano et al. 2002)]. Actin cytoskeleton has been implicated also in regulated exocytosis. It has been proposed that in secretory cells, actin network under the plasma membrane acts as a physical 
barrier preventing the access of secretory granules to the membrane. The level of total actin protein evaluated by western blotting has been found similar in GK/Par and W islets [Movassat, unpublished data], at variance with reports in others GK rat lines [Nagamatsu et al. 1999; Gaisano et al. 2002]. However, confocal analysis of the distribution of phalloidinstained cortical actin filaments revealed a higher density of the cortical actin web nearby the plasma membrane in GK/Par islets as compared to W. Moreover preliminary functional results suggest that the higher density of actin cortical web in the GK/Par islets contribute to the defects in glucose-induced insulin secretion exhibited by GK islets [Movassat, unpublished data].

Other intriguing aspects of possible mechanisms behind defective glucose-induced insulin release in GK/Sto rat islets are the findings of dysfunction of islet lysosomal enzymes [Salehi et al. 1999], as well as marked impairment of the glucose-heme oxygenase-carbon monoxide signaling pathway [Mosén et al. 2005]. Diminished levels and/or abnormal activation of several PKC isoenzymes in GK/Sto islets could also account for the defective signals downstream to glucose metabolism, responsible for impaired insulin secretion [Warwar et al. 2006]. Peroxovanadium is an inhibitor of islet protein-tyrosine phosphatase (PTP) activities that was shown to enhance glucose-stimulated insulin secretion from GK/Sto islets [Abella et al. 2003; Chen and Ostenson, 2005]. One possible target for this effect could be PTP sigma that is overexpressed in GK/Sto islets [Ostenson et al. 2002]. In addition, defects in islet protein histidine phosphorylation have been proposed to contribute to impaired insulin release in GK/Sea islets [Kowluru, 2003].

Considerable interest has recently been focused on the putative role of oxidative stress upon deterioration of beta-cell function/survival in diabetes. T2D in the GK/Jap rats is indeed associated with beta-cell oxidative damages as attested by increased levels 8-OHdG and 4hydroxy-2-nonenal-modified proteins [Ihara et al. 1999], and treatment of GK/Jap rats with anti-oxydants provided some protection from glucose toxicity [Ihara et al. 2000]. Recent data from our group indicate that the GK/Par beta-cell phenotype resulted in a reduced sensitivity to the acute deleterious effect of to streptozotocin or $\mathrm{H}_{2} \mathrm{O}_{2}$ upon the glucose-induced insulin secretion together with an increased expression of the antioxidant gene glutathione peroxydase-1 [Portha et al. 2007]. This suggests that an increased expression of antioxidants may confer paradoxically greater ROS scavenging capacity to the GK/Par beta-cell.

Figure 4 illustrates a compendium of the abnormal intracellular sites so far identified in the diabetic GK islets from the different sources.

There are several arguments indicating that the GK beta-cell secretory failure is, at least partially, related to the abnormal metabolic environment (gluco-lipotoxicity). When studied under in vitro static incubation conditions, islets isolated from normoglycaemic (prediabetic) GK/Par pups, amplified their secretory response to high glucose, leucine or leucine plus glutamine to the same extent as age-related Wislets [Portha et al. 2001]. This suggests that there does not exist a major intrinsic secretory defect in the prediabetic GK/Par beta-cells which can be considered as normally glucose-competent at this stage, at least when tested in vitro. In the GK/Par rat, basal hyperglycemia and normal to very mild hypertriglyceridemia are observed only after weaning [Portha et al. 2001]. The onset of a profound alteration in glucose-stimulated insulin secretion by the GK/Par beta cell (after weaning) is time-correlated with the exposure to the diabetic milieu. These changes in islet function could be ascribed, at least in part, to a loss of differentiation of beta cells chronically exposed to even mild chronic hyperglycemia and elevated plasma non-esterified fatty acids. The view that the lack of beta-cell reactivity to glucose as seen during the adult period when the GK rats are hyperglycemic in the basal state, at least partly reflects an acquired defect 
ascribed to gluco-lipotoxicity, is supported by the reports that chronic treatment of GK rats with phlorizin partially improved glucose-induced insulin release [Nagamatsu et al. 1999; gaisano et al. 2002; Ling et al. 2001; Portha et al. 2007], while hyperlipidemia induced by high-fat feeding markedly impaired insulin secretion [Briaud et al. 2002].

However, there are now convincing indications in the GK/Sto rat, that two distinct loci encode separately defects in beta-cell glucose metabolism and insulin exocytosis [Granhall et al. 2006]. Generation of a series of congenic rat strains harboring different parts of GK/Stoderived Niddmli has recently enabled fine mapping of this locus. Congenic strains carrying the GK genotype distally in Niddmli displayed reduced insulin secretion in response to both glucose and high potassium, as well as decreased single-cell exocytosis. Interestingly, the gene encoding for transcription factor TCF7L2 is also located in this locus and has recently been identified as a candidate gene for T2D in humans [Grant et al. 2006]. However, Tcf7L2 RNA levels were not different in this GK strain compared with controls [Granhall et al. 2006]. By contrast, the strain carrying the GK genotype proximally in Niddm1i exhibited both intact insulin release in response to high potassium and intact single-cell exocytosis, but insulin secretion was suppressed when stimulated by glucose. Islets from this strain also failed to respond to glucose by increasing the cellular ATP-to-ADP ratio. Since the congenics had not developed overt hyperglycemia and their beta-cell mass was found normal, it was concluded their functional defects in glucose metabolism and insulin exocytosis were encoded by two distinct loci within Niddm1i [Granhall et al. 2006].

In conclusion, careful comparison of the alterations so far detected in the T2D human beta-cell population and those found in the diabetic GK beta-cell population (as it is summarized in Table 2), put into the front stage a number of striking commonalities. To the best of our knowledge, none of the rodent models of spontaneous T2D so far available have revealed so close appropriateness for modelling the human diabetic beta-cell. Of course, the GK beta-cell is not a blueprint for the diseased beta-cell in human. There are however sufficient similarities with high value, to justify more efforts to understand the aetiopathogenesis of T2D in this rat model.

\section{Acknowledgments}

The GK studies done at UMR 7059 have been funded by the Centre National de la Recherche Scientifique, the French ANR (programme Physio 2006 - Prograbeta), the EFSD/MSD European Foundation, MERCK-SERONO, French Diabetes Association and NEB Research Foundation. G. Lacraz is a recipient of a doctoral fellowship from the Ministère de l'Education Nationale, de l'Enseignement Supérieur et de la Recherche. 


\section{References}

Abdel-Halim, S.M., Guenifi, A., Efendic, S., Östenson, C-G., 1993. Both somatostatin and insulin responses to glucose are impaired in the perfused pancreas of the spontaneously noninsulin ependent diabetic GK (Goto-Kakizaki) rat. Acta Physiol. Scand. 148, 219-226.

Abdel-Halim, S.M., Guenifi, A., Luthman,H., Grill, V., Efendic, S., Ostenson CG., 1994. Impact of diabetic inheritance on glucose tolerance and insulin secretion in spontaneously diabetic GK-Wistar rats. Diabetes. 43, 281-288.

Abdel-Halim, S.M, Guenifi, A., Larsson, O., Berggren, P.O., Ostenson, C.G., Efendic, S. 1996. Impaired coupling of glucose signal to the exocytotic machinery in diabetic GK rats; a defect ameliorated by cAMP. Diabetes 45, 934-940.

Abdel-Halim, S.M., Guenifi, A., He, B., yang, B., Mustafa, M., Hojeberg, B., Hillert, J., Bakhiet, M., Efendic, S., 1998. Mutations in the promoter of adenylyl cyclase (AC)-III gene, overexpression of AC-III mRNA, and enhanced cAMP generation in islets from spontaneously diabetic GK rat model of type-2 diabetes. Diabetes 47, 498-504.

Abella, A., Marti, L., Camps, M., Claret, M., Fernadez-Alvarez, J., Gomis, R., Guma, A., Viguerie, N., Carpéné, C., Palacin, M., Testar, X., Zorzano, A., 2003. Semicarbazide-sensitive amine oxidase/vascular adhesion protein-1 activity exerts an antidiabetic action in GotoKakizaki rats. Diabetes 52, 1004-1013.

Ahren, B., 2005. Type 2 diabetes, insulin secretion and beta-cell mass. Current Molecular Medicine 5, 275-286.

Anello, M., Lupi, R., Spampinato, D., Piro, S., Masini, M., Boggi, U., Del Prato, S., Rabuazzo, A.M., Purrello, F., Marchetti, P., 2005. Functional and morphological alterations of mitochondria in pancreatic beta cells from type 2 diabetic patients. Diabetologia 48, 282289.

Atef, N., Portha, B., Penicaud, L., 1994.Changes in islet blood flow in rats with NIDDM. Diabetologia 37, 677-680.

Baetens, D., Malaisse, W., Perrelet, A., Orci, L., 1979. Endocrine pancreas: three dimensional reconstruction shows two types of islets of Langerhans. Science 206, 1323-1325.

Briaud, I., Kelpe, C.L., Johnson, L.M., Tran, P.O., Poitout, V., 2002. Differential effects of hyperlipidemia on insulin secretion in islets of Langerhans from hyperglycemic versus normoglycemic rats. Diabetes 51, 662-668.

Butler, A.E., Janson, J., Bonner-Weir, S., Ritzel, R., Rizza, R.A., Butler, P., 2003. Beta-cell deficit and increased beta-cell apoptosis in humans with type 2 diabetes. Diabetes 52, $102-$ 110 . 
Calderari, S., Gangnerau, M.N., Meile, M.J., Portha, B., Serradas, P., 2006. Is defective pancreatic beta-cell mass environmentally programmed in Goto Kakizaki rat model of type-2 diabetes? Insights from cross-breeding studies during the suckling period. Pancreas 33, 412417.

Calderari, S., Gangnerau, M.N., Thibault, M., Meile, M.J., Alvarez, C., Kassis, N., Portha, B., Serradas, P., 2007. Defective IGF-2 and IGF-1R protein expressions in embryonic pancreas precede beta-cell mass anomaly in GK rat. Diabetologia 50, 1463-1471.

Carlsson, P.O., Jansson, L., Ostenson, C.G., Kallskog, O., 1997. Islet capillary blood pressure increase mediated by hyperglycemia in NIDDM GK rats. Diabetes 46, 947-952.

Chen, J., Östenson, C.G., 2005. Inhibition of protein-tyrosine phosphatases stimulates insulin secretion in pancreatic islets of diabetic Goto-Kakizaki rats. Pancreas 30, 314-317.

Clark, A., Wells, C.A., Buley, I.D., Cruickshank, J.K., Vanhegan, R.I., Matthews, D.R., Cooper, G.J., Holman, R.R., Turner, R.C., 1988. Islet amyloid, increased alpha cells, reduced beta cells and exocrine fibrosis; quantitive changes in pancreas in type-2 diabetes. Diabetes Res. 9, 151-160.

Clee, S.M., Attie, A.D., 2007. The genetic landscape of type 2 diabetes in mice. Endocrine Rev. 28, 48-83.

Dabelea, D., Pettitt, D.J., 2001. Intrauterine diabetic environment confers risks for type 2 diabetes mellitus and obesity in the offspring, in addition to genetic susceptibility. J. Ped. Endocrinol. Metab. 14, 1085-1091.

DeFronzo, R.A., 1988. Lilly Lecture 1987: the triumvirate: beta-cell, muscle, liver: a collusion responsible for NIDDM. Diabetes 37, 667-687.

Del Guerra, S., Lupi, R;, Marselli, L., Masini, M., Bugliani, M., Sbrana, S., Torri, S., Pollera, M., Boggi, U., Mosca, F., Del Prato, S., Marchetti, P., 2005. Functional and molecular defects of pancreatic islets in human type 2 diabetes. Diabetes 54, 727-735.

Deng, S., Vatamaniuk, M., Huang, X., Doliba, N., Lian, M.M., Frank, A., Veldedeoglu, E., Desai, N.M., Koeberlein, B., Wolf, B., Barker, C.F., Naji, A., Matschinsky, F.M., Markmann, J.F., 2004. Structural and functional abnormalities in the islets isolated from type 2 diabetic subjects. Diabetes 53, 624-632.

Derda, D.F., Miles, M.F., Schweppe, J.S., Jungmann, R.A., 1980. Cyclic AMP regulation of lactate dehydrogenase. J. Biol. Chem. 225, 11112-11121.

Dolz, M., Bailbé, D., Giroix, M-H., Calderari, S., Gangnerau, MN., Serradas, P., Rickenbach, K., Irminger, JC., Portha, B., 2005. Restitution of defective glucose-stimulated insulin secretion in diabetic GK art by acetylcholine uncovers paradoxical stimulatory effect of beta cell muscarinic receptor activation on cAMP production. Diabetes 54, 3229-3237. 
Dolz, M., Bailbé, D., Movassat, J., Le Stunff, H., Kassis, K., Giroix, M-H., Portha, B., 2006. Pivotal role of cAMP in the acute restitution of defective glucose-stimulated insulin release in diabetic GK rat by GLP-1. Diabetes 55 (Suppl. 1), A371.

Donath, M.Y., Halban, P.A., 2004. Decreased beta-cell mass in diabetes: significance, mechanisms and therapeutic implications. Diabetologia 47, 581-589.

Duarte, A., Santos, M., Seica, R., Oliveira, C., 2004. Oxidative stress affects synaptosomal $\gamma-$ aminobutyric acid and glutamate transport in diabetic rats. The role of insulin. Diabetes 53, 2110-2116.

Duggirala, R., Blangero, J., Almasy, L., Dyer, T.D., Williams, K.L., Leach, R.J., O'Connell, P., Stern, M.P., 1999. Linkage of type 2 diabetes mellitus and of age at onset to a genetic location on chromosome 10q in Mexican Americans. Am. J. Hum. Genet. 64, 1127-1140.

Ehses, JA., Perren, A., Eppler, E. Pospisilik, JA., Maor-Cahn, R., Ellingsgaard, H., Schneider, MKJ., Biollaz, G., Fontana, A., Reinecke, M., Homo-Delarche, F., Donath, M.Y., 2007a. Increased number of islet-associated macrophages in type 2 diabetes. Diabetes 56, 2356-2370.

Ehses, JA., Calderari, S., Irminger, J.C., Rickenbach, K., Serradas, S., Giroix, M-H., Egli, A., Portha, B., Donath, M.Y., Homo-Delarche, F., 2007b. Islet Inflammation in type 2 diabetes: from endothelial to beta-cell dysfunction. Current Immunol. Rev. 3, 216-232.

Eto, K., Tsubamoto, Y., Terauchi, Y., Sugiyama, T., Kishimoto, T., Takahashi, N., Yamauchi, N., Kubota, N., Murayama, S., Aizawa, T., Akanuma, Y., Aizawa, S., Kasai, H., Yazaki, Y., Kadowaki, T., 1999. Role of NADH shuttle system in glucose induced activation of mitochondrial metabolism and insulin secretion. Science 283, 981-985.

Fernandez-Alvarez, J., Conget, I., Rasschaert, J., Sener, A., Gomis, R., Malaisse, W.J., 1994. Enzymatic, metabolic and secretory patterns in human islets of type 2 (non-insulin-dependent) diabetic patients. Diabetologia 37, 177-181.

Frayling, T.M., Mc Carthy, M.I., 2007. Genetic stidies of diabetes following the advent of the genome-wide association study: where do we go from here?. Diabetologia 50, 2229-2233.

Gaisano, H.Y., Ostenson, C.G., Sheu, L., Wheeler, M.B., Efendic, S., 2002. Abnormal expression of pancreatic islet soluble N-ethylmaleimide-sensitive factor attachment protein receptors in GK rats is partially restored by phlorizin treament and accentuated by high glucose treatment. Endocrinology 143, 4218-4226.

Galli, J., Li, L.S., Glaser, A., Ostenson, C.G., Jiao, H., Fakhrai-Rad, H., Jacob, H.J., Lander, E., S., Luthman, H., 1996. Genetic analysis of non-insulin-dependent diabetes mellitus in the GK rat. Nat. Genet. 12, 31-37.

Gauguier, D., Nelson, I., Bernard, C., Parent, V., Marsac, C., Cohen, D., Froguel, P., 1994. Higher than paternal inheritence of diabetes in GK rats. Diabetes 43, 220-224. 
Gauguier, D., Froguel, P., Parent, V., Bernard C., Bihoreau, M.T., Portha, B., James, M.R., Penicaud, L., Lathrop, M., Ktorza, A., 1996. Chromosomal mapping of genetic loci associated with non-insulin dependent diabetes in the GK rat. Nat. Genet. 12, 38-43.

Gepts, W., 1957. Contribution à l'étude morphologique des îlots de Langerhans au cours du diabete. Ann Soc Roy Sci Med Nat 10:1.

Gerich, J.E., 1998. The genetic basis of type 2 diabetes mellitus : impaired insulin secretion versus impaired insulin sensitivity. Endocrine Rev. 19, 491-503.

Ghanaat-Pour, H., Huang, Z., Lehtihet, M., Sjoholm, A., 2007. Global expression profiling of glucose-regulated genes inpancreatic islets of spontaneously diabetic Goto-Kakizaki rats. J. Mol. Endocrinol. 39, 135-150.

Gill-Randall, R., Adams, D., Ollerton, R.L., Lewis, M., Alcolado, J.C., 2004. Type 2 diabetes mellitus - genes or intrauterine environment ? An embryo transfer paradigm in rats. Diabetologia 47, 1354-1359.

Giroix, M-H., Sener, A., Portha, B., Malaisse, WJ., 1993a. Preferential alteration of oxydative relative to total glycolysis in islets of rats with inherited or acquired non-insulin dependent diabetes. Diabetologia 36, 305-309.

Giroix, M-H., Vesco, L., Portha, B., 1993b. Functional and metabolic perturbations in isolated pancreatic islets from the GK rat, a genetic model of non-insulin dependent diabetes. Endocrinology 132, 815-822.

Giroix, M-H., Sener, A., Bailbé, D., Leclercq-Meyer, V., Portha, B., Malaisse, W.J., 1993c. Metabolic, ionic and secretory response to D-glucose in islets from rats with acquired or inherited non-insulin dependent diabetes. Biochem. Med. Metab. Biol. 50, 301-321.

Giroix, M-H., Saulnier, C., Portha, B., 1999. Decreased pancreatic islet response to L-leucine in the spontaneously diabetic GK rat: enzymatic, metabolic and secretory data. Diabetologia $42,965-977$

Goto, Y., Kakizaki, M., Masaki, N., 1975. Spontaneous diabetes produced by selective breeding of normal Wistar rats. Proc. Jpn. Acad. 51, 80-85.

Goto, Y., Suzuki, K-I., Sasaki, M., Ono, T., Abe, S., 1988. GK rat as a model of nonobese, noninsulindependent diabetes. Selective breeding over 35 generations. In: Shafrir, E., Renold, A.E. (ed.), Lessons from Animal Diabetes. Libbey, London, pp. 301-303.

Granhall, C., Rosengren, A.H., Renström, E., Luthman, H., 2006. Separately inherited defects in insulin exocytosis and beta-cell glucose metabolism contribute to type 2 diabetes. Diabetes $55,3494-3500$.

Grant, S.F., Thorleifsson, G., Reynisdottir, I., Benediktsson, R., Manolescu, A., Sainz, J., Helgason, A., Stefansson, H., Emilsson, V., Helgadottir, A., Styrkarsdottir., U, Magnusson, K.P., Walters, G.B., Palsdottir, E., Jonsdottir, T., Gudmundsdottir, T., Gylfason, A., Saemundsdottir, J., Wilensky, R.L., Reilly, M.P., Rader, D.J., Bagger, Y., Christiansen, C., 
Gudnason, V., Sigurdsson, G., Thorsteinsdottir, U., Gulcher, J.R., Kong, A., Stefansson, K., 2006. Variant of transcription factor 7-like 2 (TCF7L2) gene confers risk of type 2 diabetes. Nat. Genet. 38, 320-323.

Guenifi, A., Abdel-Halim, S.M., Höög, A., Falkmer, S., Ostenson, C.G., 1995. Preserved beta-cell density in the endocrine pancreas of young, spontaneously diabetic Goto-Kakizaki (GK) rats. Pancreas 10, 148-153.

Guenifi, A., Simonsson, E., Karlsson, S., Ahren, B., Abdel-Halim, S.M., 2001. Carbachol restores insulin release in diabetic GK rat islets by mechanisms largely involving hydrolysis of diacylglycerol and direct interaction with the exocytotic machinery. Pancreas 22, 164-171.

Guest, P.C., Abdel-Halim, S.M., Gross, D.J., Clark, A., Poitout, V., Amaria, R., Ostenson, C.G., Hutton, J.C., 2002. Proinsulin processing in the diabetic Goto-Kakizaki rat. J. Endocrinol. 175, 637-647.

Guiot, Y., Sempoux, C., Moulin, P., Rahier, J., 2001. No decrease of the beta-cell mass in type 2 diabetic patients. Diabetes 50 (Suppl. 1), S188.

Gunton, J.E., Kulkarni, R.N., Yim, S.H., Okada, T., Hawthorne, W.J., Tseng, Y.H., Roberson, R.S., O'Connell, P.J., Ricordi, C., Gonzalez, F.J., Kahn C.R., 2005. Loss of ARNT/HIF1 beta mediates altered gene expression and pancreatic-islet dysfunction in human type 2 diabetes. Cell 122, 337-349.

Gutniak, M., Orskov, C., Holst, J.J., Ahren, B., Efendic, S., 1992. Antidiabetogenic effect of glucagon-like peptide 1 (7-36) amide in normal subjects and patients with diabetes mellitus. N. Engl. J. Med. 326, 1316-1322.

Hellerström, C., 1984. The life story of the pancreatic beta cell. Diabetologia 26, 393-400.

Homo-Delarche, F., Calderari, S., Irminger, J.C., Rickenbach, K., Gangnerau, MN., Coulaud, J., Dolz, M., Halban, P., Portha, B., Serradas, S., 2006. Islet Inflammation and fibrosis in a spontaneous model of type 2 diabetes, the GK Rat. Diabetes 55, 1625-1633.

Hughes, S.J., Suzuki, K., Goto, Y., 1994. The role of islet secretory function in the development of diabetes in the GK Wistar rat. Diabetologia 37, 863-870.

Hughes, S.J., Faehling, M., Thorneley, C.W., Proks, P., Ashcroft, F.M., Smith, P.A., 1998. Electrophysiological and metabolic characterization of single beta-cells and islets from diabetic GK rats. Diabetes 47, 73-81.

Ihara, Y., Toyokuni, S., Uchida, K., Odaka, H., Tanaka, T., Ikeda, H., Hiai, H., Seino, Y., Yamada, Y., 1999. Hyperglycemia causes oxidative stress in pancreatic beta-cells of GK rats, a model of type 2 diabetes. Diabetes 48, 927-932.

Ihara, Y., Yamada, Y., Toyokuni, S., Miyawaki, K., Ban, N., Adachi, T., Kuroe, A., Iwakura, T., Kubota, A., Hiai, H., Seino, Y., 2000. Antioxidant alpha-tocopherol ameliorates glycemic control of GK rats, a model of type 2 diabetes. FEBS Lett. 473, 24-26. 
Jones, L.C., Clark, A., 2001. Beta-cell neogenesis in Type 2 Diabetes 50 (Suppl. 1), 186-187.

Kahn, S., 2001. The importance of beta-cell failure in the development and progression of type 2 diabetes mellitus. J. Clin. Endocrinol. Metab. 86, 4047-4058.

Kloppel, G., Mattias, L., Habich, K., Oberholzer, M., Heitz, P.U., 1985. Islet pathology and the pathogenesis of type1 and type 2 diabetes mellitus revisited. Surv. Synth. Pathol. Res. 4, $110-125$.

Kowluru, A., 2003. Defective protein histidine phosphorylation in islets from the GotoKakizaki diabetic rat. Am. J. Physiol. 285, E498-E503.

Krauss, S., Zhang, C.Y., Scorrano, L., Dalgaard, L.T., St-Pierre, J., Grey, S.T., Lowell, B.B., 2003. Superoxide-mediated activation of uncoupling protein 2 causes pancreatic beta-cell dysfunction. J. Clin. Invest. 112, 1831-1842.

Laakso, M., 2007. Challenges in studies of the genetic basis of type 2 diabetes. Expert Rev. Endocrinol. Metab. 2, 451-459.

Lewis, B., Ismail, I., Issa, B., Peters, J.R., Scanlon, M.F., 1996. Desensitization of somatostatin, TRH and GHRH responses to glucose in the diabetic GK rat hypothalamus. J. Endocrinol. 151, 13-17.

Lin, J.M., Ortsäter, H., Fakhraid-Rad, H., Galli, J., Luthman, H., Bergsten, P., 2001. Phenotyping of individual pancreatic islets locates genetic defects in stimulus secretion coupling to Niddm1i within the major diabetes locus in GK rats. Diabetes 50, 2737-2743.

Lin, J.M., Fabregat, M.E., Gomis, R., Bergsten, P., 2002. Pulsatile insulin release from islets isolated from three subjects with type 2 diabetes. Diabetes 51, 988-993.

Ling, Z.C., Efendic, S., Wibom, R., Abdel-halim, S.M., Ostenson, C.G., Landau, B.R., Khan, A., 1998. Glucose metabolism in Goto-Kakizaki rat islets. Endocrinology 139: 2670-2675.

Ling, Z.C., Hong-Lie, C., Ostenson, C.G., Efendic, S., Khan, A., 2001. Hyperglycemia contributes to impaired insulin response in GK rat islets. Diabetes 50 (Suppl.1), 108-112.

Lyssenko, V., Lupi, R., Marchetti, P., Del Guerra, S., Orho-Melandr, M., Almgren, P., Sjogren, M., Ling, C., Eriksson, K.F., Lethagen, A.L., Mancarella, R., Berglund, G., Tuomi, T., Nilsson, P., Del Prato, S., Groop, L., 2007. Mechanisms by which common variants in the TCF7L2 gene increase risk of type 2 diabetes. J. Clin. Invest. 117, 215562163.

MacDonald, M.J., Efendic, S., Östenson, C-G., 1996. Normalization by insulin treatment of low mitochondrial glycerol phosphate dehydrogenase and pyruvate carboxylase in pancreatic islets of the GK rat. Diabetes 45, 886-890.

Maclean, N., Ogilvie, R., 1955. Quantitative estimation of the pancreatic islet tissue in diabetic subjects. Diabetes 4:367-376. 
Marchetti, P., Dotta, F., Ling, Z., Lupi, R., Del Guerra, S., Santangelo, C., Realacci, M., Marselli, L., Di Mario, U., Navalesi, R., 2000. Function of pancreatic islets isolated from a type 1 diabetic patient. Diabetes Care 23, 701-703.

Marchetti, P., Del Guerra, S., Marselli, L., Lupi, R., Masini, M., Pollera, M., Bugliani, M., Boggi, U., Vistoli, F., Mosca, F., Del Prato, S., 2004. Pancreatic islets from type 2 diabetic patients have functional effects and increased apoptosis that are meliorated by metformin. $\mathrm{J}$. Clin. Endocrinol. Metab. 89, 5535-5541.

Marchetti, P., Bugliani, M., Lupi, R., Marselli, L., Masini, M., Boggi, U., Weir, GC., Eizirik, D., Cnop, M., 2007. The endoplasmic reticulum in pancreatic beat cells of type 2 diabetes patients. Diabetologia 50, 2486-2494.

Marie, J.C., Bailbé, D., Gylfe, E., Portha, B., 2001. Defective glucose-dependent cytosolic $\mathrm{Ca} 2+$ handling in islets of GK and $\mathrm{nSTZ}$ rat models of type 2 diabetes. J. Endocrinol. 169, 169-176.

Metz, S.A., Meredith, M., Vadakekalam, J., Rabaglia, M.E., Kowluru, A.A., 1999. A defect late in stimulus secretion coupling impairs insulin secretion in Goto-Kakizaki diabetic rats. Diabetes 48, 1754-1762.

Miralles, F., Portha, B., 2001. Early development of beta-cells is impaired in the GK rat model of type2 diabetes. Diabetes 50 (Suppl.1), 84-88.

Mosén, H., Salehi, A., Alm, P., Henningsson, R., Jimenez-Feltstrom, J., Ostenson, C.G., Efendic, S., Lundquist, I., 2005. Defective glucose-stimulated insulin release in the diabetic Goto-Kakizaki (GK) rat coincides with reduced activity of the islet carbon monoxide signaling pathway. Endocrinology 146, 1553-1558.

Movassat, J., Portha, B., 1999. Beta-cell growth in the neonatal Goto-Kakizaki rat and regeneration after treatment with streptozotocin at birth. Diabetologia 42, 1098-1106.

Movassat, J., Calderari, S., Fernández, E., Martín, MA., Escrivá, F., Plachot, C., Gangnerau, MN., P. Serradas, P., Álvarez, C., Portha, B., 2007. Type 2 Diabetes - A Matter of Failing Beta-Cell Neogenesis ? Clues from the GK rat model. Diabetes Obesity Metabolism 9, 187195.

Movassat, J., Saulnier, C., Serradas, P., Portha, B., 1997. Impaired development of pancreatic beta-cell mass is a primary event during the progression to diabetes in the GK rat. Diabetologia 40, 916-925.

Nagamatsu, S., Nakamichi, Y., Yamamura, C., Matsushima, S., Watanabe, T., Azawa, S., Furukawa, H., Ishida, H., 1999. Decreased expression of t-SNARE, syntaxin 1, and SNAP-25 in pancreatic beta-cells is involved in impaired insulin secretion from diabetic GK rat islets: Restoration of decreased t-SNARE proteins improves impaired insulin secretion. Diabetes 48, $2367-2373$.

Ohara-Imaizumi, M., Nishiwaki, C., Kikuta, T., Nagai, S., Nakamichi, Y., Nagamatsu, S., 2004. TIRF imaging of docking and fusion of single insulin granule motion in primary rat 
pancreatic beta-cells: Different behaviour of granule motion between normal and GotoKakizaki diabetic rat beta-cells. Biochem. J. 381, 13-18.

O’Brien, T.D., Butler, A.E., Roche, P.C., Johnson, K.H., Butler, P.C., 1994. Islet amyloid polypeptide in human insulinomas: evidence for intracellular amyloidogenesis. Diabetes 43, 329-336.

Ohneda, M., Johnson, J.H., Inman, L.R., Chen, L., Suzuki, K.I., Goto, Y., Alam, T., Ravazzola, M., Orci, L., Unger, R.H., 1993. GLUT2 expression and function in $\beta$-cells of GK rats with NIDDM. Diabetes 42, 1065-1072.

Okamoto, Y., Ishida, H., Tsuura, Y., Yasuda, K., Kato, S. Matsubara, H., Nishimura, M., Mizuno, N., Ikeda, H., Seino, Y., 1995. Hyperresponse in calcium-induced insulin release from electrically permeabilized pancreatic islets of diabetic GK rats and its defective augmentation by glucose. Diabetologia 38, 772-778.

Orci, L., Malaisse-Lagae, F., Amherdt, M., Ravazzola, M., Weisswange, A., Dobbs, R., Perrelet, A., Unger, R., 1975. Cell contacts in human islets of Langerhans. J. Clin. Endocrinol. Metab. 41, 841-844.

Östenson, C.G., Abdel-Halim, S.M., Rasschaert, J., Malaisse-Lagae, F., Meuris, S., Sener, A., Efendic, S., Malaisse, W.J., 1993a. Deficient activity of FAD-linked glycerophosphate dehydrogenase in islets of GK rats. Diabetologia 36, 722-726.

Östenson, C.G., Khan, A., Abdel-Halim, S.M., Guenifi, A., Suzuki, K., Goto, Y,. Efendic, E., 1993b. Abnormal insulin secretion and glucose metabolism in pancreatic islets from the spontaneously diabetic GK rat. Diabetologia 36, 3-8.

Östenson, C.G., 2001. The Goto-Kakizaki rat. In: Sima, A.A.F., Shafrir, E., (ed.), Animal Models of Diabetes: A Primer. Harwood Academic Publishers, Amsterdam, pp. 197-211.

Östenson, C.G., Sandberg-Nordqvist, A.C., Chen, J., Hallbrink, M., Rotin, D., Langel, U., EFendic, S., 2002. Overexpression of protein tyrosine phosphatase PTP sigma is linked to impaired glucose-induced insulin secretion in hereditary diabetic Goto-Kakizaki rats. Biochem. Biophys. Res. Commun. 291, 945-950.

Ostenson, C., Gaisano, H., Sheu, L., Tibell, A., Bartfai, T., 2006. Impaired gene and protein expression of exocytotic soluble N-ethylmaleimide attachment protein receptor complex proteins in pancreatic islets of type 2 diabetic patients. Diabetes 55, 435-440.

Plachot, C., Movassat, J., Portha, B., 2001. Impaired beta-cell regeneration after spatial pancreatectomy in the adult Goto-Kakizaki rat, a spontaneous model of type 2 diabetes. Histochem. Cell. Biol. 116, 131-139.

Polonsky, K.S., Given, B.D., Hirsch, L.J., Tillil, H., Shapiro, E.T., Beebe, C., Frank, B.H., Galloway, J.A., Van Cauter, E., 1998. Abnormal patterns of insulin secretion in non-insulindependent diabetes mellitus. N. Engl. J. Med. 318, 1231-1239. 
Portha, B., Serradas, P., Bailbé, D., Suzuki, K., Goto, Y., Giroix, M-H., 1991. $\beta$-Cell insensitivity to glucose in the GK rat, a spontaneous nonobese model for type II diabetes. Diabetes 40, 486-491.

Portha, B., Giroix, M-H., Serradas, P. P, Gangnerau, MN., Movassat, J., Rajas, F., Bailbé, D., Plachot, C., Mithieux, G., Marie, J.C., 2001. Beta-cell function and viability in the spontaneously diabetic GK rat. Information from the GK/Par colony. Diabetes 50, 89-93.

Portha, B., 2005. Programmed disorders of beta-cell development and function as one cause for type 2 diabetes ?. The GK rat paradigm. Diab. Metab. Res. Rev. 21, 495-504.

Portha, B., Lacraz, G., Dolz, M., Giroix, MH., Homo-Delarche, F., Movassat, J., 2007. Issues surrounding beta-cells and their roles role I type 2 diabetes. What tell us the GK rat model. Expert Rev. Endocrinol. Metab. 2, 785-795.

Rahier, J., Goebbels, R.M., Henquin, J.C., 1983. Cellular composition of the human diabetic pancreas. Diabetologia 24, 366-371.

Rhodes, C.J., 2005. Type 2 diabetes - a matter of beta-cell life and death?. Science 307, 380384 .

Saito, K., Yaginuma, N., Takahashi, T., 1979. Differential volumetry of A, B and D cells in the pancreatic islets of diabetic and nondiabetic subjects. Tohoku J Exp Med 129:273-283.

Sakuraba, H., Mizukami, H., Yagihashi, N., Wada, R., Hanyu, C., Yagihashi, S., 2002. Reduced beta-cell mass and expression of oxidative stress-related DNA damage in the islet of Japanese type II diabetic patients. Diabetologia 45, 85-96.

Salehi, A., Henningsson, R., Mosén, H., Ostenson, C.G., Efendic, S., Lundquist, I., 1999. Dysfunction of the islet lysosomal system conveys impairment of glucose-induced insulin release in the diabetic GK rat. Endocrinology 140, 3045-3053.

Schmitz, O., Brock, B., Hollingdal, M., Juhl, C.B., Porksen, N., 2002. High-frequency insulin pulsatility and type 2 diabetes: from physiology and pathophysiology to clinical pharmacology. Diabetes Metab. 28, 4S14-4S20.

Sempoux, C., Guiot, Y., Dubois, D., Moulin, P., Rahier, J., 2001. Morphological evidence for abnormal beta-cell function. Diabetes 50 (Suppl. 1), S172-S177.

Sener, A., Ladrière, L., Malaisse, W.J., 2001. Assessment by D-[(3)H]mannoheptulose uptake of B-cell density in isolated pancreatic islets from Goto-Kakizaki rats. Int. J. Mol. Med. 8, 177-180.

Serradas, P., Goya, L., Lacorne, M., Gangnerau, MN., Ramos, S., Alvarez, C., Pascual-Leone, AM., Portha, B., 2002. Fetal insulin-like growth factor-2 production is impaired in the GK rat model of type 2 diabetes. Diabetes 51, 392-397. 
Serradas, P, Gangnerau, MN, Giroix, MH, Saulnier, C, Portha, B., 1998. Impaired pancreatic beta cell function in the fetal GK rat. Impact of diabetic inheritance. J. Clin. Invest. 101, 899904.

Serradas, P., Giroix, M-H., Saulnier, C., Gangnerau, M.N., Borg, L.A.H., Welsh, M., Portha, B., Welsh, N., 1995. Mitochondrial DNA content is specifically decreased in adult, but not fetal, pancreatic islets of the GK rat, a genetic model of non-insulin dependent diabetes. Endocrinology 136, 5623-5631.

Shang, W., Yasuda, K., Takahashi, A., Hamasaki, A., Takehiro, M., Nabe, K., Zhou, H., Naito, R., Fujiwara, H., Shimono, D., Ueno, H., Ikeda, H., Toyoda, K., Yamada, Y., Kurose, T., 2002. Effect of high dietary fat on insulin secretion in genetically diabetic Goto-Kakizaki rats. Pancreas 25, 393-399.

Simmons, R., 2006. Developmental origins of adult metabolic disease. Endocrinol. Metab. Clin. N. Am. 35, 193-204.

Stefan, Y., Orci, L., Malaisse-Lagae, F., Perrelet, A., Patel, Y., Unger, RH., 1982. Quantitation of endocrine cell content in the pancreas of nondiabetic and diabetic humans. Diabetes 31, 694-700.

Suzuki, K-I., Goto, Y., Toyota, T., 1992. Spontaneously diabetic GK (Goto-Kakizaki) rats. In: Shafrir, E. (ed.), Lessons from Animal Diabetes. Smith-Gordon, London, pp. 107-116.

Suzuki, N., Aizawa, T., Asanuma, N., Sato, Y., Komatsu, M., Hidaka, H., Itoh, N., Yamauchi, K., Hashizume, K., 1997. An early insulin intervention accelerates pancreatic $\beta$-cell dysfunction in young Goto-Kakizaki rats, a model of naturally occurring noninsulindependent diabetes. Endocrinology 138, 1106-1110.

Svensson, A.M., Östenson, C.G., Sandler, S., Efendic, S., Jansson, L., 1994. Inhibition of nitric oxide synthase by NG-nitro-L-arginine causes a preferential decrease in pancreatic islet blood flow in normal rats and spontaneously diabetic GK rats. Endocrinology 135, 849-853.

Svensson, A.M., Ostenson, C.G., Jansson, L., 2000. Age-induced changes in pancreatic islet blood flow: evidence for an impaired regulation in diabetic GK rats. Am. J. Physiol. Endocrinol. Metab. 279, E1139-E1144.

Tsuura, Y., Ishida, H., Okamoto, Y., K, Kato, S., Sakamoto, K., Horie, M., Ikeda, H., Okada, Y., Seino, Y., 1993. Glucose sensitivity of ATP-sensitive Kchannels is impaired in beta-cells of the GK rat. Diabetes 42, 1446-1453.

Villar-Palasi, C., Farese, R., 1994. Impaired skeletal muscle glycogen synthase activation by insulin in the Goto-Kakizaki (GK) rat. Diabetologia 37, 885-888.

Wallis, R.H., Wallace, K.J., Collins, S.C. Mc Ateer, M., Argoud, K., Bihoreau, M.T., Kaisaki, P.J., Gauguier, D., 2004. Enhanced insulin secretion and cholesterol metabolism in congenic strains of the spontaneously diabetic (type2) Goto Kakizaki rat are controlled by independent genetic loci in rat chromosome 8. Diabetologia 47, 1096-1106. 
Warwar, N., Efendic, S., Östenson, C.G., Haber, E.P., Cerasi, E., Nesher, R., 2006. Dynamics of glucose-induced localization of PKC isoenzymes in pancreatic $\beta$-cells. Diabetes-related changes in the GK rat. Diabetes 55, 590-599.

Weir, G., Bonner-Weir, S., 2004. Five stages of evolving beta-cell dysfunction during progression to diabetes. Diabetes 53 (suppl), S16-S21.

Westermark, P., Wilander, E., 1978. The influence of amyloid deposits on the islet volume in maturity onset diabetes mellitus. Diabetologia 15, 417-421.

Weyer, C., Bogardus, C., Mott, D., Prateley, R., 1999. The natural history of insulin secretory dysfunction and insulin resistance in the pathogenesis of type 2 diabetes mellitus. J. Clin. Invest. 104, 787-794.

Wittingen, J., Frey, C.F., 1974. Islet concentration in the head, body, tail and uncinate process of the pancreas. Ann. Surg. 412-414.

Yoon, K.H., Ko, S.H., Cho, J.H., Lee, J.M., Son, H.Y., Kang, S.K., Kim, H.S., Lee, I.K., Boner-Weir, S., 2003. Selective beta-cell loss and alpha-cell expansion in patients with type 2 diabetes mellitus in Korea. J. Clin. Endocrinol. Metab. 8, 2300-2308.

Zhang, W., Khan, A., Ostenson, C., Berggren, P.O., Efendic, S., Meister, B., 2002. Downregulated expression of exocytotic proteins in pancreatic islets of diabetic GK rats. Biochem. Biophys. Res. Commun. 291, 1038-1044.

Zhao, H.L., Lai, F., Tong, P., Zhong, D.R., Yang, D., Tomlinson, B., Chan, J., 2003. Prevalence and clinicopathological characteristics of islet amyloid in chinese patients with type 2 diabetes. Diabetes 52, 2759-2766.

Zhou, Y.P., Ostenson, C., Ling, Z.C., Grill, V., 1995. Deficiency of pyruvate dehydrogenase activity in pancreatic islets of diabetic GK rats. Endocrinology 136, 3546-3551. 


\section{Legends to Figures}

\section{Figure 1:}

Insulin (upper panels) and glucagon release (lower panels) in GK/Par (blue symbols, $n=5$ and $\mathrm{GK} / \mathrm{Tac}$ (from commercial source, Taconic) (red symbols, $\mathrm{n}=6$ ) male rat pancreases (isolated perfused pancreases) in the presence of $16.7 \mathrm{mM}$ glucose or $19 \mathrm{mM}$ arginine. When not otherwise indicated, the perfusion medium (KRB) contained no glucose.

\section{Figure 2:}

Model for defective glucose-induced insulin release and the abnormal intracellular sites so far identified in the beta-cells obtained from humans with T2D.

Where data are available, the impaired sites in the beta-cell are indicated with the symbol: Abbreviations: Glut: glucose transporter; AC, adenylate cyclases; Gas, Gaq: $\alpha$ subunits of heterotrimeric G proteins; G $\beta \gamma$ : $\beta$ and $\gamma$ subunits of heterotrimeric G proteins; PI, PIP, PIP2: phosphoinositides; PLC: phospholipase C; PKC: protein kinase C; DAG: diacylglycerol; IP3: inositol-3-phosphate; UCP2: uncoupling protein 2; tSNARE, v-SNARE: SNARE proteins (syntaxin-1A, SNAP-25, VAMP-2, Munc 18, Munc 13-1, synaptophysin); L-VOCC: L-type calcium chanel modulated by the membrane polarisation; CC/IPR3: calcium chanel modulated by recptor to IP3; K/ATP C: potassium chanel modulated by the ATP/ADP ratio; $\mathrm{Ca}^{2+} / \mathrm{CamK}$ : calcium calmoduline kinase; Ach: acetylcholine; M3-R: muscarinic receptor isoform 3; GLP-1: glucagon-like peptide 1; GLP1-R: GLP1 receptor;

\section{Figure 3:}

mRNA expression was altered in islets freshly isolated from adult (8-wk-old) diabetic or neonatal (1-wk-old) prediabetic GK/Par rats. Quantitative real-time PCR was used to measure expression in islets with age-matched correction for expression of the control S18 gene.

Of the cAMP metabolism genes, adenylyl cyclase isoforms 2 (AC-2) and 3 (AC-3) together with the $\alpha$ subunits $G \alpha_{\mathrm{s}}$ and and $G \alpha_{\text {olf }}$ of the heterotrimeric $G$ proteins, were significantly increased in adult GK islets when compared to adult control Wistar islets. By contrast, their expression in neonatal GK rats islets did not differ significantly from the controls. This is consistent with the view that the increased cAMP production by adult GK islets reflects an acquired adaptation possibly ascribed to gluco-lipotoxicity.

Concerning some proteins involved in glucose metabolism pathway or control of mitochondrial oxidative phosphorylation, hexokinase-1 (HK-1), lactate-dehydrogenase A (LDH-A), glucose-6-phosphatase (G6Pase) and uncoupling protein-2 (UCP-2) were significantly increased in adult GK islets when compared to adult control Wistar islets. By contrast, their expression in neonatal GK rats islets did not differ significantly from the controls.

$* \mathrm{p}<0.01$ as compared to age-related control group.

\section{Figure 4:}

Model for defective glucose-induced insulin release and the abnormal intracellular sites so far identified in the beta-cell of the diabetic GK rats from the different sources.

Where data are available, the impaired sites in the beta-cell are indicated with the symbol: Abbreviations: Glut2: glucose transporter isoform 2; Leu: leucine; KIC: keto-isocaproate; AC:

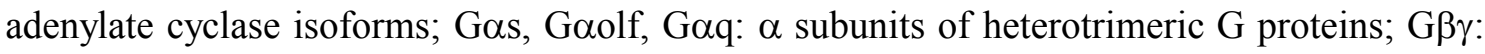
$\beta$ and $\gamma$ subunits of heterotrimeric G proteins; PI, PIP, PIP2: phosphoinositides; PLC: phospholipase C; PKC: protein kinase C; DAG: diacylglycerol; IP3: inositol-3-phosphate; UCP2: uncoupling protein 2; tSNARE, v-SNARE: SNARE proteins (syntaxin-1A, SNAP-25, 
VAMP-2, Munc 18); L-VOCC: L-type calcium chanel modulated by the membrane polarisation; CC/IPR3: calcium chanel modulated by receptor to IP3; K/ATP C: potassium chanel modulated by the ATP/ADP ratio; $\mathrm{Ca}^{2+} / \mathrm{CamK}$ : calcium calmoduline kinase; Ach: acetylcholine; M3-R: muscarinic receptor isoform 3; GLP-1: glucagon-like peptide 1; GLP1$\mathrm{R}$ : GLP1 receptor; PDE: cAMP-dependant phosphodiesterase isoforms. 


\begin{tabular}{|c|c|c|c|c|c|c|c|c|c|}
\hline \multicolumn{2}{|c|}{ Pancreas/Islet/Beta-Cell Phenotype } & \multirow[t]{2}{*}{ GK/Par } & \multirow[t]{2}{*}{ GK/Jap } & \multirow[t]{2}{*}{ GK/Sto } & \multirow[t]{2}{*}{ GK/UK } & \multirow[t]{2}{*}{ GK/Dal } & \multirow[t]{2}{*}{ GK/Sea } & \multirow[t]{2}{*}{ GK/Coi } & \multirow[t]{2}{*}{ GK/Tac } \\
\hline & + & & & & & & & & \\
\hline \multicolumn{2}{|c|}{ Reduction in beta cell mass compared with age-/weight-matched controls } & $\sqrt{ }$ & $\sqrt{ }$ & no & ? & ? & ? & ? & $?$ \\
\hline & Normal beta-cell apoptosis & $\sqrt{ }$ & $\sqrt{ }$ & no & ? & ? & ? & ? & ? \\
\hline & \begin{tabular}{|l|} 
Reduced beta-cell proliferation \\
Decreased beta-cell neogenesis
\end{tabular} & $\sqrt{ }$ & $\sqrt{ }$ & $\sqrt{ }$ & $?$ & $?$ & $?$ & $?$ & $?$ \\
\hline & Decreased beta-cell neogenesis & $\sqrt{ }$ & $?$ & $?$ & $?$ & $?$ & $?$ & $?$ & $?$ \\
\hline & Slightly decreased alpha cell proportion within the islets & $\sqrt{ }$ & ? & no & $?$ & ? & $?$ & $?$ & $?$ \\
\hline Perturbed microenvironme & ent within and around the islets & $\sqrt{ }$ & $\sqrt{ }$ & $?$ & ? & ? & $?$ & ? & ? \\
\hline & $\begin{array}{l}\text { Fibrosis, arteriosclerosis, fat infiltration } \\
\text { Macrophage infiltration of the islets }\end{array}$ & $\sqrt{ }$ & $\sqrt{ }$ & ? & ? & ? & $?$ & $?$ & ? \\
\hline Multiple beta-cell functiona & $\begin{array}{l}\text { Macrophage infiltration of the islets } \\
\text { al defects }\end{array}$ & $\sqrt{ }$ & $\sqrt{ }$ & $\sqrt{ }$ & $\sqrt{ }$ & $\sqrt{ }$ & $\sqrt{ }$ & $\sqrt{ }$ & $?$ \\
\hline & Maintenance of active proinsulin gene transcription and translation & $\sqrt{ }$ & $?$ & $\sqrt{ }$ & $?$ & $?$ & $?$ & $?$ & $?$ \\
\hline & Normal proinsulin biosynthesis and processing & $\sqrt{ }$ & $\sqrt{ }$ & $\sqrt{ }$ & $\sqrt{ }$ & ? & ? & ? & ? \\
\hline & $\begin{array}{l}\text { Slight decrease of beta-cell insulin content } \\
\text { Markedlv reduced activity of the insulin release mechanism especially in response to glucose }\end{array}$ & $\sqrt{ }$ & $\sqrt{ }$ & $\sqrt{ }$ & $\sqrt{ }$ & $\sqrt{ }$ & no & $\sqrt{ }$ & $?$ \\
\hline & Markedly reduced activity of the insulin release mechanism, especially in response to glucose & $\sqrt{ }$ & $\sqrt{ }$ & $\sqrt{ }$ & $\sqrt{ }$ & $\sqrt{ }$ & $\sqrt{ }$ & $\sqrt{ }$ & $\sqrt{ }$ \\
\hline & \begin{tabular}{l|l} 
& Reduced GLUT2 expression/glucose uptake \\
\end{tabular} & no & no & no & no & $\sqrt{ }$ & $?$ & $?$ & $?$ \\
\hline & Reduced glucokinase expression/glucose phosphorylation & no & no & no & ? & ? & $?$ & $?$ & $?$ \\
\hline & Decreased islet glucose oxidation/glycolysis ratio & $\sqrt{ }$ & $\sqrt{ }$ & $\sqrt{/} /$ no & $\sqrt{ }$ & ? & ? & ? & ? \\
\hline & Reduced FAD-glycerophosphate dehydrogenase activity & $\sqrt{ }$ & $\sqrt{ }$ & $\sqrt{ }$ & ? & ? & ? & ? & ? \\
\hline & Lower ATP/ADP ratio in response to glucose & $\sqrt{ }$ & $?$ & $\sqrt{ } / \mathrm{no}$ & $\sqrt{ }$ & $?$ & no & $?$ & ? \\
\hline & Impaired islet calcium metabolism & $\sqrt{ }$ & $\sqrt{ }$ & $\sqrt{ }$ & $\sqrt{ }$ & ? & $?$ & ? & ? \\
\hline & Decreased activation of islet PI kinases and phospholipase $\mathrm{C}$ by glucose & $\sqrt{ }$ & ? & ? & ? & ? & $\sqrt{ }$ & ? & ? \\
\hline & $\begin{array}{l}\text { increase basal islet cAMP level, in relation to increased expression of AC1, AC2, } \\
A C 3, G \alpha S, G \alpha \text { olf }\end{array}$ & $\sqrt{ }$ & ? & $\sqrt{ }$ & ? & $?$ & ? & ? & $?$ \\
\hline & Increased expression of UCP-2 & $\sqrt{ }$ & $?$ & $\sqrt{ }$ & ? & $?$ & $\sqrt{ }$ & $?$ & ? \\
\hline & Increased islet levels of nitrotyrosine and 8-hydroxy-2-deoxyguanosine & ? & $\sqrt{ }$ & ? & ? & ? & ? & ? & ? \\
\hline & $\begin{array}{l}\text { Increased expression of manganese-superoxide and Cu/Zn superoxide } \\
\text { dismutases }\end{array}$ & $\sqrt{ }$ & ? & ? & ? & ? & $?$ & ? & $?$ \\
\hline & Increased expression of catalase and glutathione peroxidase & $\sqrt{ }$ & ? & ? & ? & ? & ? & ? & ? \\
\hline & $\begin{array}{l}\text { Reduced expression of islet SNAREs and SNARE-modulating proteins: } \\
\text { synaptotagmin, VAMP-2, syntaxin-1A,SNAP-25, nSec1 and Munc 13-1 }\end{array}$ & $\sqrt{ }$ & $\sqrt{ }$ & $\sqrt{ }$ & ? & ? & ? & ? & $?$ \\
\hline & Increased actin expression & no & $\sqrt{ }$ & $\sqrt{ }$ & $?$ & $?$ & $?$ & $?$ & $?$ \\
\hline \multicolumn{2}{|c|}{ Beta-cell responsiveness to sulfonylureas and GLP1 } & $\sqrt{ }$ & $\sqrt{ }$ & $\sqrt{ }$ & $\sqrt{ }$ & ? & $\sqrt{ }$ & ? & ? \\
\hline \multirow{2}{*}{\multicolumn{2}{|c|}{$\begin{array}{l}\text { Polygenic aetiology } \\
\text { Maternal hyperglycemia in pregnancy is an environmental risk factor } f\end{array}$}} & $\sqrt{ }$ & $?$ & $\sqrt{ }$ & ? & $?$ & ? & $?$ & ? \\
\hline & & $\sqrt{ }$ & ? & ? & ? & ? & ? & ? & ? \\
\hline
\end{tabular}




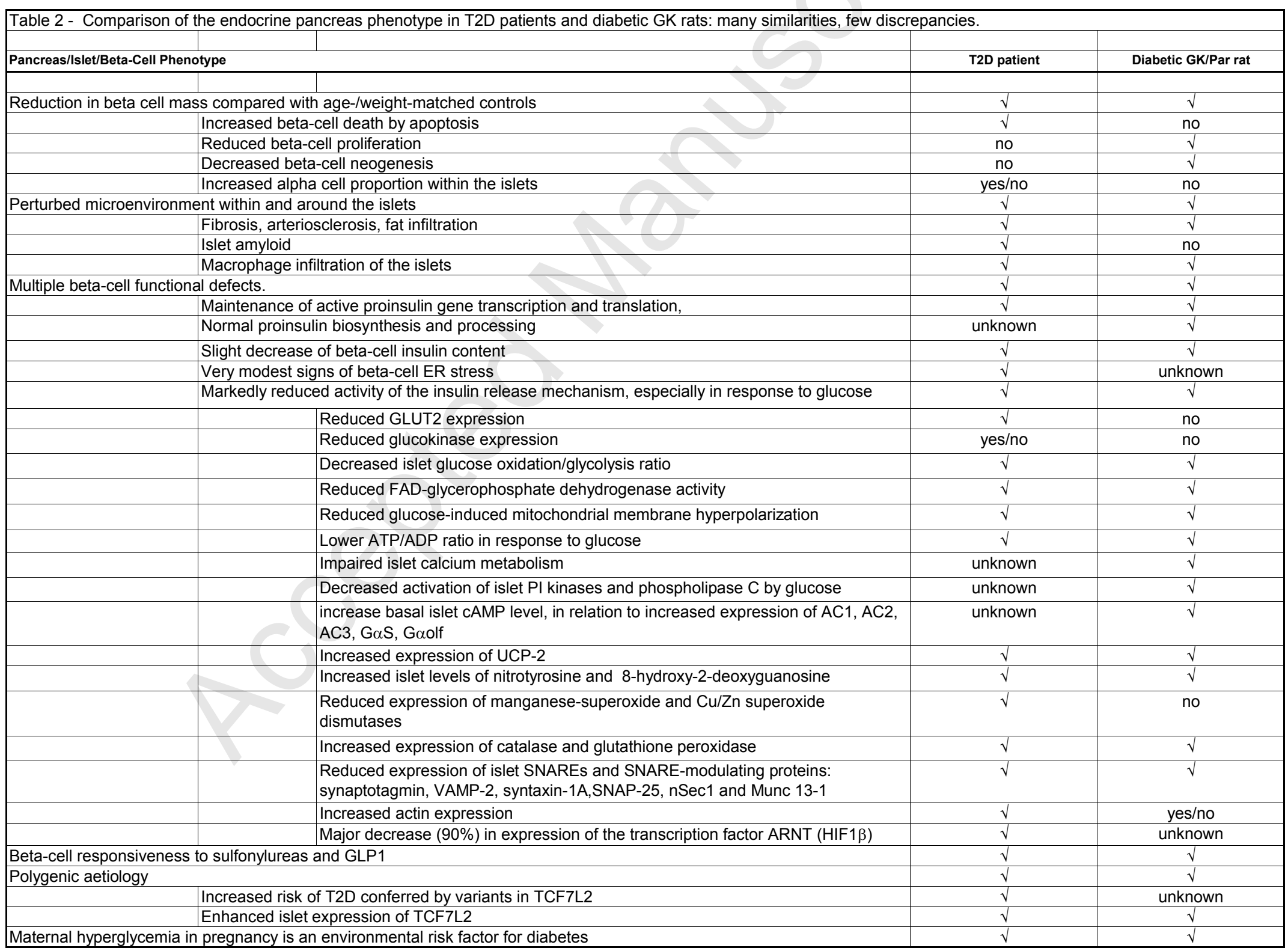



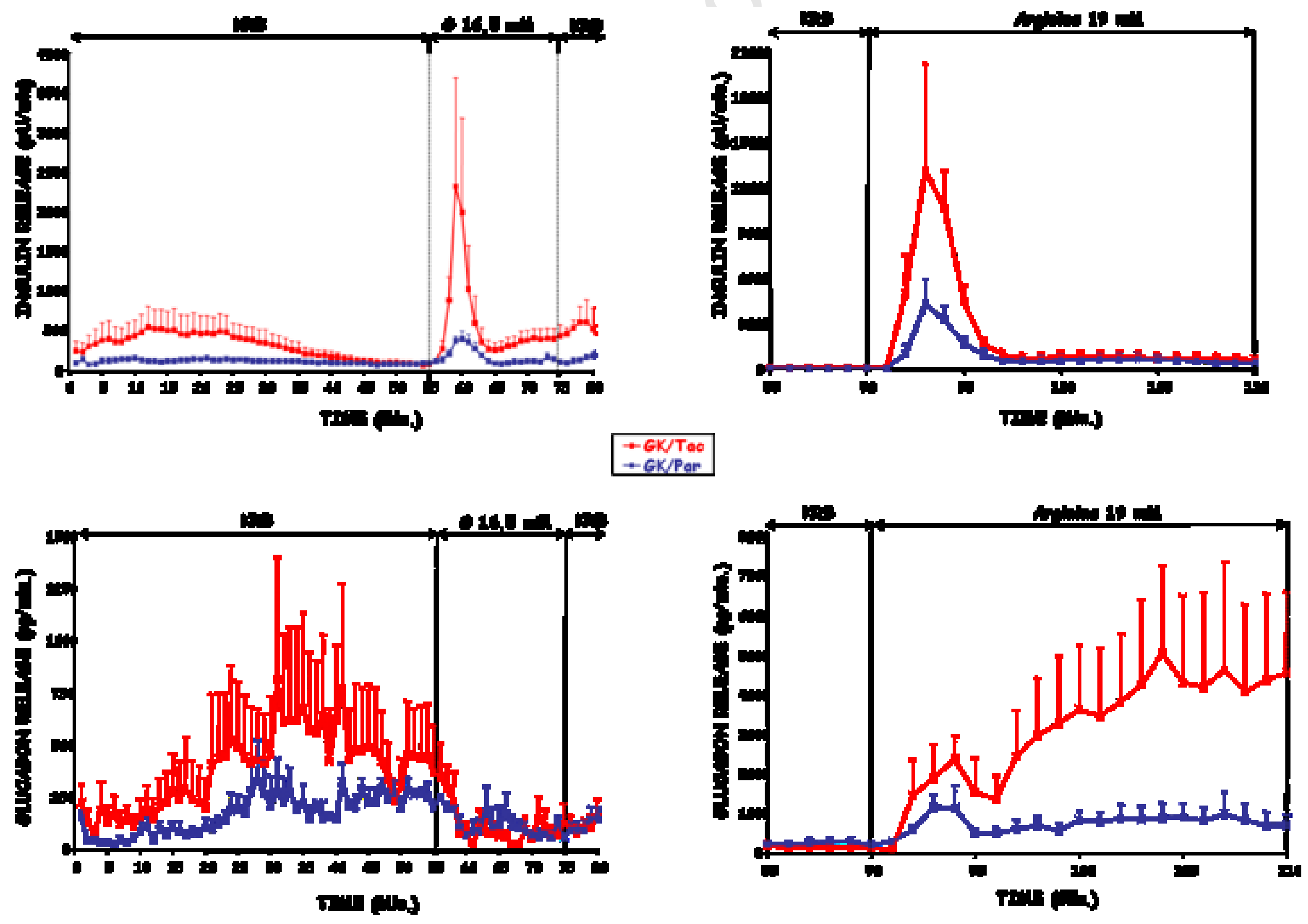

Page 31 of 33 


\section{Deturous}

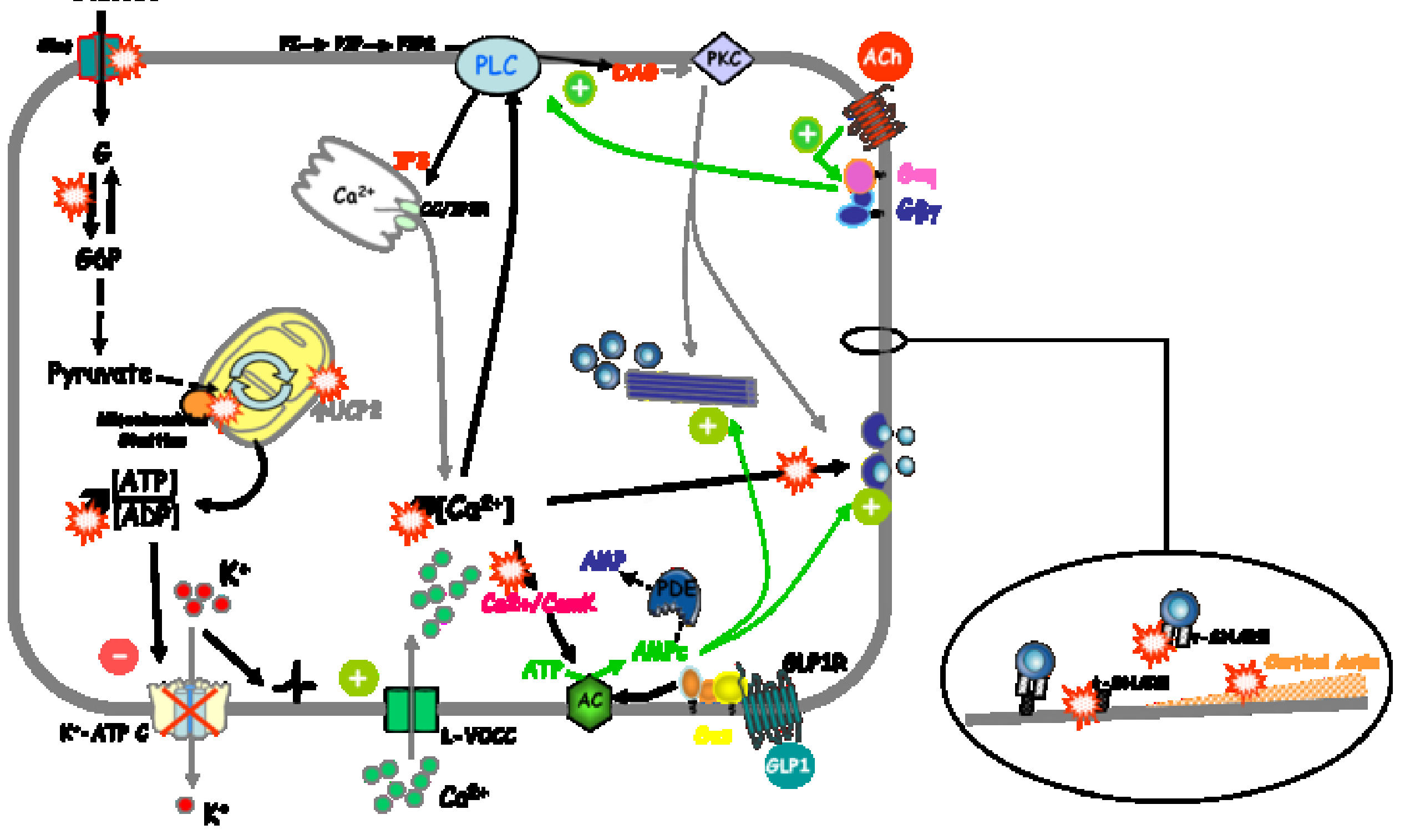

